\title{
Recent Progress in the Neoadjuvant Treatment Strategy for Locally Advanced Esophageal Cancer
}

\author{
Sicong Hou ${ }^{1,+}+{ }^{-}$, Ziyin Pan ${ }^{2,+}$, Xin Hao ${ }^{2}$, Qinglei Hang ${ }^{3, *(\mathbb{D}}$ and Yanbing Ding ${ }^{1, *}$ \\ 1 Department of Gastroenterology, Affiliated Hospital of Yangzhou University, Yangzhou University, \\ Yangzhou 225000, China; shou@yzu.edu.cn \\ 2 Department of Clinical Medicine, Medical College, Yangzhou University, Yangzhou 225001, China; \\ pan_ziyin@126.com (Z.P.); yzdxhx@163.com (X.H.) \\ 3 Department of Experimental Radiation Oncology, The University of Texas MD Anderson Cancer Center, \\ Houston, TX 77030, USA \\ * $\quad$ Correspondence: ybding@yzu.edu.cn (Y.D.); hq1219@hotmail.com (Q.H.); Tel.: +86-514-8298-1199 (Y.D.); \\ +86-138-1458-885 (Q.H.) \\ + These authors contributed equally to this work.
}

check for updates

Citation: Hou, S.; Pan, Z.; Hao, X.; Hang, Q.; Ding, Y. Recent Progress in the Neoadjuvant Treatment Strategy for Locally Advanced Esophageal Cancer. Cancers 2021, 13, 5162. https://doi.org/10.3390/

cancers13205162

Academic Editor: Bas P.L. Wijnhoven

Received: 10 September 2021

Accepted: 5 October 2021

Published: 14 October 2021

Publisher's Note: MDPI stays neutral with regard to jurisdictional claims in published maps and institutional affiliations.

Copyright: (c) 2021 by the authors. Licensee MDPI, Basel, Switzerland. This article is an open access article distributed under the terms and conditions of the Creative Commons Attribution (CC BY) license (https:/ / creativecommons.org/licenses/by/ $4.0 /)$.
Simple Summary: Neoadjuvant therapy is recommended as standard care for patients with locally advanced resectable esophageal cancer. Neoadjuvant chemotherapy (nCT) and chemoradiotherapy (nCRT) have convincingly been shown to improve the survival rate compared with surgery alone based on the results of several randomized clinical trials. Immunotherapy has become a new research direction in the field of EC research due to its great curative effects. However, controversies still remain in regard to identifying the most appropriate combination of $\mathrm{nCT}, \mathrm{nCRT}$, immunotherapy, and surgery, optimizing more effective neoadjuvant treatment protocols and surveillance strategies. This review comprehensively summarizes the research progress and describes and discusses the outcomes, pros, and cons of current trials. We believe our work has great academic value and will be of great help for researchers to understand the domestic and foreign research status in the field of neoadjuvant therapy in EC.

Abstract: Neoadjuvant therapies, primarily chemotherapy and chemoradiotherapy, are able to improve the overall survival (OS) in patients with locally advanced resectable esophageal cancer (EC) based on the results of several randomized clinical trials. The advantage of neoadjuvant therapy is chiefly attributed to the decreased risk of local-regional recurrence and distant metastasis. Thus, it has been recommended as standard treatment for patients with resectable EC. However, several fundamental problems remain. First, the combination of neoadjuvant chemotherapy (nCT), neoadjuvant chemoradiotherapy (nCRT), and surgery for EC patients with different histological types remain controversial. Furthermore, to reduce the toxicity of preoperative chemotherapy and the risk of complications caused by preoperative radiation therapy, the treatment protocols of nCT and nCRT still need to be investigated and optimized by prospective trials. Moreover, for patients with complete clinical response following neoadjuvant therapy, it is worth ascertaining whether a "watch and wait" surveillance plus surgery-as-needed policy is more favorable, as well as, in addition to preoperative chemoradiotherapy, whether immunotherapy, especially when combined with the traditional neoadjuvant therapy regimens, brings new prospects for EC treatment. In this review, we summarize the recent insights into the research progress and existing problems of neoadjuvant therapy for locally advanced resectable EC.

Keywords: esophageal cancer; neoadjuvant therapy; chemotherapy; chemoradiotherapy; immunotherapy; esophagectomy; active surveillance 


\section{Introduction}

Esophageal cancer $(\mathrm{EC})$ is the seventh most commonly diagnosed cancer and the sixthleading cause of cancer-related death globally according to the statistics in 2020 from the American Cancer Society [1]. Even though esophagectomy is the cornerstone of treatment for locally advanced EC, the loco-regional and distant recurrences still bother nearly half of the patients after surgery [2]. To improve the clinical outcomes, neoadjuvant therapies have been introduced to the curative treatment. The MAGIC and OEO2 trials solidified the role of neoadjuvant chemotherapy (nCT), while the CROSS trial laid the foundation of neoadjuvant chemoradiotherapy (nCRT) for resectable EC [3-5]. Although both nCT and nCRT showed the overall survival (OS) benefit compared to surgery alone, current available evidence has not yet supported a clear advantage of nCRT over nCT [6-8]. The clinical outcome to different neoadjuvant therapy was also associated with the histological subtypes [9,10]. Despite nCRT and $\mathrm{nCT}$ exhibiting a high tumor response to patients with squamous cell carcinoma (SCC) and adenocarcinoma (AC), the nCRT group showed higher sensitivity and significant improvement of survival in SCC patients, while the tumor response was not translated to survival advantages in AC patients [9,11-13]. In addition to the efficiency, the treatment protocols of $\mathrm{nCT}$ and $\mathrm{nCRT}$ also need to consider the toxicity and complications risk. Nowadays, immune-based approaches have shown great potential in EC treatment, which has resulted in a better curative effect when combined with nCT or nCRT regimens $[10,14]$. Thus, the optimal treatment remains to be determined. In this review, we summarized of the recent insights into the research progress and existing problems of neoadjuvant therapy for EC.

\section{Neoadjuvant Chemotherapy}

\subsection{Neoadjuvant Chemotherapy Versus Surgery Alone}

Chemotherapy works locally and systematically by downgrading the primary tumor to increase the chance of radical resection and elimination of (subclinical) micrometastases, thereby reducing the risk of distant metastases [15]. The safety and efficacy of nCT have gradually been recognized in the field of EC research. The addition of $\mathrm{nCT}$ to the treatment regimen for esophageal and gastro-esophageal junction (GEJ) carcinoma was recommended mainly based on the results of several large randomized clinical trials (RCTs) [16,17]. We have made a summary of several pivotal trials in Table 1.

Table 1. Clinical trials of nCT versus surgery alone for EC patients.

\begin{tabular}{|c|c|c|c|c|c|c|c|c|c|c|}
\hline Trial & Histologic Subtype & TNM Stage & Intervention & $\begin{array}{c}\text { Patients } \\
(n)\end{array}$ & CT & $\begin{array}{l}\mathrm{R} 0 \\
(\%)\end{array}$ & $\begin{array}{c}\text { MST } \\
\text { (Months) }\end{array}$ & $\begin{array}{c}\text { OS (\%) } \\
(1 ; 2 ; 3 ; 4 ; 5 \text { Years) }\end{array}$ & $\begin{array}{l}\text { Postoperative } \\
\text { Morbidity (\%) }\end{array}$ & $\begin{array}{l}\text { Postoperative } \\
\text { Mortality (\%) }\end{array}$ \\
\hline $\begin{array}{c}\text { MRC } \\
2002[18]\end{array}$ & $\mathrm{AC}, \mathrm{SCC}$ & NA & $\begin{array}{c}\mathrm{nCT} \rightarrow \mathrm{S} \\
\mathrm{S}\end{array}$ & $\begin{array}{l}400 \\
402\end{array}$ & $\begin{array}{c}\text { CF } \\
\text { (2 cycles) }\end{array}$ & $\begin{array}{l}60 \\
54\end{array}$ & $\begin{array}{l}16.8 \\
13.3\end{array}$ & $\begin{array}{l}-; 43 ;-;-;-; \\
-; 34 ;-;-;-\end{array}$ & NA & $\begin{array}{l}10 \\
10\end{array}$ \\
\hline $\begin{array}{l}\text { MAGIC } \\
2006[4]\end{array}$ & AC & $\begin{array}{l}\text { T1-4, } \\
\text { N0-3 }\end{array}$ & $\begin{array}{c}\mathrm{nCT} \rightarrow \mathrm{S} \\
\mathrm{S}\end{array}$ & $\begin{array}{l}250 \\
253\end{array}$ & $\begin{array}{c}\text { ECF } \\
(3 \text { cycles })\end{array}$ & $\begin{array}{l}69 \\
66\end{array}$ & NA & $\begin{array}{l}-;-;-;-; 36.3 \\
-;-;-;-; 23\end{array}$ & $\begin{array}{l}46 \\
45\end{array}$ & $\begin{array}{l}5.6 \\
5.9\end{array}$ \\
\hline $\begin{array}{c}\mathrm{OEO} 2 \\
2009[5]\end{array}$ & $\mathrm{AC}, \mathrm{SCC}$ & NA & $\begin{array}{c}\mathrm{nCT} \rightarrow \mathrm{S} \\
\mathrm{S}\end{array}$ & $\begin{array}{l}400 \\
402 \\
\end{array}$ & $\begin{array}{c}\text { CF } \\
\text { (2 cycles) }\end{array}$ & $\begin{array}{l}60 \\
54\end{array}$ & NA & $\begin{array}{l}-;-;-; ;-; 23 \\
-;-;-;-; 17.1\end{array}$ & NA & NA \\
\hline $\begin{array}{l}\text { FNCLCC/FFCD } \\
2011[19]\end{array}$ & AC & T0-4, N0, N+ & $\begin{array}{c}\mathrm{nCT} \rightarrow \mathrm{S} \\
\mathrm{S}\end{array}$ & $\begin{array}{l}113 \\
111\end{array}$ & $\begin{array}{c}\text { CF } \\
\text { (2 or 3 cycles) }\end{array}$ & $\begin{array}{l}84 \\
74\end{array}$ & NA & $\begin{array}{l}-;-;-;-; 38 \\
-;-;-;-; 24\end{array}$ & NA & $\begin{array}{l}4.6 \\
4.5\end{array}$ \\
\hline $\begin{array}{l}\text { Fiteni et al., } \\
2016 \text { [20] }\end{array}$ & AC & $\begin{array}{c}\text { T0-4, } \\
\text { N0-N3 }\end{array}$ & $\begin{array}{l}\mathrm{nCT} \rightarrow \mathrm{S} \\
\mathrm{S}\end{array}$ & $\begin{array}{c}62 \\
789\end{array}$ & $\begin{array}{c}\text { DCF } \\
(\geq 1 \text { cycle })\end{array}$ & $\begin{array}{l}93 \\
85\end{array}$ & $\begin{array}{l}57 \\
22\end{array}$ & $\begin{array}{l}-;-; 67 ;-;- \\
\text { NA }\end{array}$ & $\begin{array}{l}34 \\
52\end{array}$ & $\begin{array}{l}3.2 \\
2.9\end{array}$ \\
\hline $\begin{array}{l}\text { JCOG } 9907 \\
2012[21]\end{array}$ & SCC & $\begin{array}{l}\text { T2-3, } \\
\text { N0-1 }\end{array}$ & $\begin{array}{l}\mathrm{nCT} \rightarrow \mathrm{S} \\
\mathrm{S}\end{array}$ & $\begin{array}{l}164 \\
166\end{array}$ & $\begin{array}{c}\mathrm{CF} \\
(\geq 1 \text { cycle })\end{array}$ & $\begin{array}{l}96 \\
91\end{array}$ & NA & $\begin{array}{l}-;-;-;-; 444 \\
-;-;-;-; 39\end{array}$ & NA & NA \\
\hline
\end{tabular}

TNM, tumor-node-metastasis; CT, chemotherapy; R0, complete macroscopic and microscopic tumor resection; MST, median survival time; OS, overall survival; $\mathrm{nCT}$, neoadjuvant chemotherapy; S, surgery; SCC, squamous cell carcinoma; AC, adenocarcinoma; NA, not available; CF, cisplatin/5-fluorouracil; ECF, epirubicin/cisplatin/5-fluorouracil; DCF, docetaxel/cisplatin/5-fluorouracil.

As early as 2002, a large randomized controlled multicenter study was conducted by England Medical Research Council (MRC) with a sample of 802 patients with resectable EC (nCT: 400 cases; surgery alone: 402 cases) [18]. The chemotherapy used in the nCT group consisted of two courses of concurrent administration of cisplatin/5-fluorouracil (CDDP/5-FU, CF). The results showed that $\mathrm{nCT}$ significantly enhanced the R0 resection rate $(60 \%$ vs. $54 \%)$, increased the median survival time (16.8 months vs. 13.3 months), and prolonged the 2-year survival rate ( $43 \%$ vs. $34 \%$ ) compared to surgery alone. Moreover, 
patients with SCC and AC had the same risk ratio for treatment outcomes, indicating that the benefit was similar for both histological types. In 2009, a long-term update of the MRC trial called the UK OEO2-trial was conducted, which randomly categorized 802 patients with AC and SCC from 1992 to 1999 into two 4-day cycles of CF (cisplatin: $80 \mathrm{mg} / \mathrm{m}^{2}$, fluorouracil: $1000 \mathrm{mg} / \mathrm{m}^{2}$ ) and immediate surgery alone. It was the first trial to identify a significant OS benefit in nCT group compared with surgery alone. Both histological subgroups showed a survival benefit, with a 5 -year OS of $23 \%$ for AC and $26 \%$ for SCC ( $p$ for interaction $=0.81$ ). The OS benefit can be attributed to the large sample size of the trial and the significant improvement in R0 resections in the nCT group ( $60 \%$ vs. $54 \%$ ). However, this study found no difference in distant metastasis rates between the two groups, suggesting a comparatively modest systematic benefit of this chemotherapy regimen [5]. The USA RTOG-trial 8911 enrolled 440 patients, and the nCT regimen turned to three cycles of cisplatin $\left(100 \mathrm{mg} / \mathrm{m}^{2}\right)$ and continuous infusion of fluorouracil $\left(1000 \mathrm{mg} / \mathrm{m}^{2}\right)$ for four days, followed by surgery. Inconsistent with the results of the OEO2-trial, the RTOG trial showed no improvement in local control and OS rate. A possible explanation may be due to the toxicity of the RTOG-trial's nCT regimen related to a larger amount of cisplatin [22]. Thus, the dosage of cisplatin in CF regimen needs follow-up research to optimize. Although over ten years have passed, the MRC-OEO2 trial still offers great value. Hale et al. [23] collected the digital $\mathrm{H} / \mathrm{E}$ stained pre-treatment biopsy slides from 281 patients in the MRC-OEO2 trial (141 treated with surgery alone and 140 treated with surgery after $\mathrm{nCT}$ ). The study investigated the predictive effect of the proportion of tumor cells per tumor area (PoT) measured in pre-treatment biopsies on the treatment benefit of nCT. The results showed a non-linear relationship between PoT and survival, and only patients with PoT between $40 \%$ and $70 \%$ gained significant benefit from $\mathrm{nCT}$, suggesting for the first time that PoT may be clinically used as a biomarker for patients' treatment stratification. Further research should focus on improving the prediction model through detailed quantitative morphology and molecular characterization of intratumoral substrate to better understand the underlying biological process, ultimately enhancing EC treatment stratification. Similarly, in another series of original research, Sundar's team, for the first time continued to conduct DNA methylation analysis of 229 surgically resected specimens from $\mathrm{AC}$ patients in the OEO2-trial to identify an epigenetic signature that can serve as a predictive biomarker for the benefit of $\mathrm{CF}$ regimen. It is expected to be used for risk stratification and biomarker selection in future AC studies [24].

To further improve survival outcomes, several large RCTs have studied a combination of neoadjuvant and adjuvant chemotherapy, i.e., perioperative chemotherapy. As for the MAGIC trial, 503 patients from 1994 to 2002 were randomized into perioperative chemotherapy and surgery alone. These patients were diagnosed with resectable gastric adenocarcinoma, GEJ, and lower esophageal adenocarcinoma. The chemotherapy regimens included epirubicin, cisplatin, and 5-FU (ECF) for three preoperative and postoperative cycles. The results showed that perioperative chemotherapy significantly increased the 3 - and 5 -year OS from $31 \%$ to $44 \%$ and $23 \%$ to $36.3 \%$, and decreased distant metastases from $37 \%$ to $24 \%$, respectively. Preoperative chemotherapy reduced the tumor size in all patients but had limited effects on R0 resection rates [4]. However, since only $25 \%$ of participants in the trial had GEJ or lower EAC, the results of this study cannot be extrapolated to all patients with EC without dispute. To cope with this problem, the FNCLCC/FFCD trial randomized 224 patients (more than 70\% of all tumors located in the lower esophagus or the GEJ). This trial found a significant OS benefit ( $38 \%$ vs. $24 \%$ ) in the perioperative CF group compared to surgery alone, as well as an $8 \%$ reduction in distant recurrence rates, parallel to results in the MAGIC trial. Furthermore, the FNCLCC/FFCD trial exhibited a significantly improved $\mathrm{R} 0$ resection rate in the $\mathrm{nCT}$ group compared to surgery alone ( $84 \%$ vs. $74 \%$ ) [19]. Last but not least, the JCOG9907 trial in 2012 confirmed the benefits of using perioperative chemotherapy using $\mathrm{CF}$ regimen as a standard approach in resectable stage II/III SCC [21]. 
In recent years, the combined chemotherapy using docetaxel, cisplatin, and 5-FU (DCF) has been consistently proven to bring more favorable outcomes in EC. Ojima et al. [25] reported that among patients with clinical stage II/III SCC, a divided-dose DCF regimen yielded a high frequency of pathological response. Hara et al. [26] found that the DCF regimen had strong antitumor activity and was proven to be safe and tolerable for patients with clinical stage II/III SCC. In another prospective multicenter phase I/II study, Satake et al. [27] reported positive oncologic outcomes, as well as bearable post-operative complications and excellent OS performance after using neoadjuvant DCF protocols. As a result, in order to gain more insight into the relative efficacy of DCF regimen, Fiteni's research team evaluated the efficacy of DCF as perioperative chemotherapy versus surgery alone in a large multicenter comparison cohort of patients with resectable GEA [20]. The trial identified 789 patients who underwent surgery only and 62 patients who received at least one cycle of DCF regimen (docetaxel $75 \mathrm{mg} / \mathrm{m}^{2}$ on day 1, cisplatin $75 \mathrm{mg} / \mathrm{m}^{2}$ on day 1, 5-FU $750 \mathrm{mg} / \mathrm{m}^{2} /$ day on continuous perfusion for 5 days) every 3 weeks. In contrast with the surgery group, the chemotherapy group had a better survival rate, higher 3-year OS rate and pathological complete response (pCR), but the improvement of R0 resection rate was not statistically significant. More extensive randomized phase III trials are still needed in the future to explore the potential survival benefit of docetaxel in the perioperative period of resectable GEA. The latest Korean PRODIGY trial and the German NEO-FLOT trial are under way to see whether an updated combination regimen for $\mathrm{nCT}$ can bring superior clinical efficacy.

\subsection{Progression and Optimization in the Treatment Protocols of $n C T$}

In Japan, esophagectomy followed by two courses of neoadjuvant chemotherapy with $\mathrm{CF}$ is considered to be the standard strategy for the treatment of patients with advanced or recurrent EC. Although the results from the subgroup analysis of the JCOG9907 trial showed that CF regimens were able to benefit patients with clinical stage III SCC, patients' survival was limited, indicating the need for different effective regimens [21,28]. We have made comparisons between some different treatment protocols for nCTs and results are shown in Table 2. OEO5 is an open-label phase-III RCT which enrolled 897 patients with resectable AC between 2005 and 2011 who were randomized to four cycles of nCT with epirubicin, cisplatin, and capecitabine (ECX) or two cycles of CF regimen. The results suggested that compared with the CF group, more patients in the ECX group had a good pathological response to chemotherapy (Mandard tumor regression grade 1 or 2) and showed a significant down-staging effect with ypT0 or ypT1 or ypN0. However, no increase was found in patient survival. The median overall survival and disease-free survival expectancy were calculated to be 23.4 months (95\% CI 20.6-26.3) and 11.6 months (95\% CI 8.9-13.3) in CF group versus 26.1 months (95\% CI 22.5-29.7) and 14.4 months (95\% CI 11.7-16.5) in ECX group. In addition, there was no obvious 3-year OS benefit either (ECX group: 42\% vs. CF group: 39\%) [29]. The FLOT-4 trial, presented at the American Society of Clinical Oncology meeting, received significant attention [30]. Patients with stomach or GEJAC underwent four preoperative and four postoperative cycles of FLOT (fluorouracil, leucovorin, oxaliplatin, docetaxel), and another group of patients received three preoperative and postoperative cycles of ECF/ECX. The results showed that the pCR rate significantly increased by $10 \%$ in FLOT group compared with ECF/ECX group (16\% vs. $6 \%$ ). After a median follow-up of 43 months, FLOT significantly improved the median and 5-year OS rates, from 35 months to 50 months and from $36 \%$ to $45 \%$, respectively. FLOT is now considered as one of the standards of care for AC patients [31]. 
Table 2. Comparison between different regimens of nCT.

\begin{tabular}{|c|c|c|c|c|c|c|c|c|c|c|c|c|}
\hline Trial & $\begin{array}{l}\text { Histologic } \\
\text { Subtype }\end{array}$ & TNM Stage & Intervention & Patients $(n)$ & $\mathrm{nCT}$ & $\begin{array}{l}\mathrm{R} 0 \\
(\%)\end{array}$ & $\begin{array}{l}\text { pCR } \\
(\%)\end{array}$ & $\begin{array}{c}\text { MST } \\
\text { (Months) }\end{array}$ & $\begin{array}{c}\text { OS (\%) } \\
(1 ; 2 ; 3 ; 4 ; 5 \text { Years) }\end{array}$ & $\begin{array}{l}\text { Median DFS } \\
\text { (Months) }\end{array}$ & $\begin{array}{l}\text { Postoperative } \\
\text { Morbidity (\%) }\end{array}$ & $\begin{array}{l}\text { Postoperative } \\
\text { Mortality (\%) }\end{array}$ \\
\hline \multirow{2}{*}{$\begin{array}{c}\mathrm{OEO} \\
2017[29]\end{array}$} & \multirow[t]{2}{*}{$\mathrm{AC}$} & \multirow{2}{*}{$\begin{array}{l}\text { T1-4, } \\
\text { No-1 }\end{array}$} & $\mathrm{nCT} \rightarrow \mathrm{S}$ & 446 & $\begin{array}{c}\text { ECX } \\
\text { (4 cycles) }\end{array}$ & 66 & \multirow[t]{2}{*}{$\mathrm{NA}$} & 26.1 & $-;-; 42 ;-;-$ & 14.4 & 62 & 3 \\
\hline & & & $\mathrm{nCT} \rightarrow \mathrm{S}$ & 451 & $\begin{array}{c}\text { CF } \\
\text { (2 cycles) }\end{array}$ & 59 & & 23.4 & $-;-; 39 ;-;-$ & 11,6 & 56 & 2 \\
\hline \multirow{2}{*}{$\begin{array}{l}\text { FLOT4 } \\
2019[30]\end{array}$} & \multirow[t]{2}{*}{ AC } & \multirow{2}{*}{$\begin{array}{l}\text { T2-4, } \\
\text { N0-3 }\end{array}$} & $\mathrm{nCT} \rightarrow \mathrm{S}$ & 360 & $\begin{array}{l}\text { ECF/ECX } \\
\text { (3 cycles) }\end{array}$ & 78 & 6 & 35 & $-; 59 ; 48 ;-; 36$ & 18 & 50 & 3 \\
\hline & & & $\mathrm{nCT} \rightarrow \mathrm{S}$ & 356 & $\begin{array}{c}\text { FLOT } \\
\text { (4 cycles) }\end{array}$ & 85 & 16 & 50 & $-; 67 ; 57-; 45$ & 30 & 51 & 2 \\
\hline \multirow{2}{*}{$\begin{array}{c}\text { OGSG1003 } \\
2017[32] \\
2020[33]\end{array}$} & \multirow[t]{2}{*}{ SCC } & \multirow{2}{*}{$\begin{array}{l}\text { T1-4a, N0-3, } \\
\text { M0-1 }\end{array}$} & $\mathrm{nCT} \rightarrow \mathrm{S}$ & 81 & $\begin{array}{c}\text { ACF } \\
(2 \text { cycles })\end{array}$ & 95.9 & \multirow[t]{2}{*}{ NA } & \multirow[t]{2}{*}{ NA } & $-; 65.4 ;-; ; ; 49.4$ & \multirow[t]{2}{*}{ NA } & \multirow[t]{2}{*}{ NA } & \multirow[t]{2}{*}{ NA } \\
\hline & & & $\mathrm{nCT} \rightarrow \mathrm{S}$ & 81 & $\begin{array}{c}\text { DCF } \\
\text { (2 cycles) }\end{array}$ & 96.2 & & & $-; 78.6 ;-; ; ; 63.5$ & & & \\
\hline $\begin{array}{l}\text { Onitilo } \\
\text { et al., } 2021 \text { [34] }\end{array}$ & $\begin{array}{l}\mathrm{AC} \\
\text { SCC }\end{array}$ & $\begin{array}{l}\text { T1-4, } \\
\text { N0-2 }\end{array}$ & $\mathrm{nCT} \rightarrow \mathrm{S}$ & $\begin{array}{c}23 \\
7\end{array}$ & $\begin{array}{c}\text { mDCF } \\
(4-6 \text { cycles })\end{array}$ & NA & NA & $\begin{array}{l}44.4 \\
76.5\end{array}$ & $\begin{array}{l}-; 64.9 ;-; ;-; 44.5 \\
-; 71.4 ;-;-; 71.4\end{array}$ & $\mathrm{NA}$ & NA & NA \\
\hline \multirow[t]{2}{*}{$\begin{array}{l}\text { Akiyama } \\
\text { et al., 2018 [35] }\end{array}$} & \multirow{2}{*}{$\mathrm{SCC}$} & \multirow{2}{*}{$\begin{array}{l}\text { T1-4b, N0-3, } \\
\text { M0-1 }\end{array}$} & $\mathrm{nCT} \rightarrow \mathrm{S}$ & 37 & DCF & \multirow{2}{*}{ NA } & 13.5 & \multirow{2}{*}{ NA } & \multirow{2}{*}{ NA } & \multirow{2}{*}{ NA } & 32.4 & 0 \\
\hline & & & $\mathrm{nCT} \rightarrow \mathrm{S}$ & 22 & bDCF & & 22.7 & & & & 45.5 & 0 \\
\hline
\end{tabular}

DFS, disease-free survival; ECX, epirubicin/cisplatin/capecitabine; ACF, adriamycin/cisplatin/5-FU; FLOT, fluorouracil/leucovorin/ oxaliplatin/docetaxel; mDCF, modified DCF; bDCF, biweekly DCF.

Although the nCT regimen DCF is of particular value for EC treatment, related research and trials are still ongoing. For resectable advance348hase II trial randomly assigned 162 patients to group DCF and ACF (adriamycin, cisplatin and 5-FU) to make a comparison between the two chemotherapy regimens [32]. The primary endpoint was recursion-free survival (RFS); the secondary endpoints were OS, R0 resection rate, histopathological response, and postoperative complications. The final results indicated that DCF had a higher 2-year RFS than ACF (64.1\% vs. $42.9 \%$ ), while the R0 resection rate was similar $(96.2 \%$ vs. $95.9 \%, p=0.93)$. In addition, DCF had significantly better histological findings on major tumor $(p<0.0001)$ and a much earlier pathological T stage $(p=0.008)$. The frequency of recurrence after operation was higher in patients treated with ACF compared with DCF $(p=0.008)$, indicating a better safety from DCF regimen. It is worth noting that no significant difference between DCF and ACF was found in OS; a possible reason is that the follow-up period was too short (34.5 months). Therefore, a follow-up study was conducted to assess the long-term outcomes and analyze the primary endpoint, RFS, as well as secondary endpoints such as OS and recurrence patterns [33]. Consistent with the preliminary results, this study confirmed a better 5-year RFS for DCF (59.9\% vs. 40.7\%). Encouragingly, the following subgroup analysis showed that the OS of the DCF group was significantly better than that of the ACF group in patients with advanced clinical T (cT3 or cT4) stage and $\mathrm{N}$ (cN2 or cN3) stage EC. In contrast, there was no difference in OS between the two groups in patients with early clinical T (cT1 or cT2) stage and N (cN0 or cN1) stage. Based on the data presented above, DCF can be seen as a potential nCT candidate for patients with clinical stage III and IV EC; as for stage I and II, a less toxic regimen should be considered. Given the fact that the DCF group had a remarkable higher control rate for local and distant lesions as well as a lower postoperative local recurrence rate, it is reasonable to speculate DCF regimen as a promising candidate for neoadjuvant therapy for resectable SCC. However, further prospective studies are still required to address the topic due to the limitation of the sample scale of the present trial. The JCOG1109 trial is currently underway in Japan, whose results will prove evidence with regard to the most suitable and effective preoperative treatment for SCC.

Despite the advantages of DCF, severe grade $3 / 4$ adverse events, especially grade 3 or 4 neutropenia in $66.2-78.2 \%$ patients and febrile neutropenia in $14.5-22.9 \%$ patients, have drawn great attention. Due to the relatively high toxicity of $\mathrm{DCF}$, some clinical studies have focused on adjusting the dose and frequency of the regimen in the hope of maintaining efficacy while reducing toxicity [36,37]. To integrate the modified DCF regimen (mDCF) into non-metastatic esophageal cancer (nMEC), a retrospective review of 30 patients diagnosed with nMEC and treated with mDCF regimen between 2008 and 2017 was performed [34]. The mDCF regimen refers to a kind of modified weekly DCF: docetaxel $40 \mathrm{mg} / \mathrm{m}^{2}$ on day 1 , cisplatin $40 \mathrm{mg} / \mathrm{m}^{2}$ on day 1,5 -FU $2000 \mathrm{mg} / \mathrm{m}^{2}$ on days $1-2$, leucovorin $400 \mathrm{mg} / \mathrm{m}^{2}$ on day 1 . The results have shown that $\mathrm{mDCF}$ is not only effective 
in nMEC and AC patients (64.9\% and $44.5 \%$ of OS at 3 and 5 years), but also reduces the incidence of severe neutropenia to only $13 \%$. In addition to the impact on AC, the mDCF regimen showed promising results for local advanced SCC, with a 71.4\% 2-year OS and a significant reduction in the incidence of grade $3 / 4$ hematologic toxic events (43\% for leukopenia and $14 \%$ for neutropenia) compared to the maternal DCF regimen. It is worth mentioning that elderly patients and patients with comorbidities account for a large proportion of EC patients, and the possibility of DCF causing adverse events increases. Therefore, the bDCF, a refined regimen in which docetaxel was divided and administered biweekly, was introduced to reduce serious adverse events in these frail patients. Akiyama et al. [35] investigated the feasibility and efficacy of esophagectomy after bDCF treatment in 59 patients with advanced SCC. The trial found that bDCF regimen brought a higher clinical response rate and a lower incidence of grade 3 or 4 neutropenia compared with DCF. Therefore, for patients with advanced SCC, the bDCF nCT regimen turned out to be feasible and safer in the perioperative period without reducing the efficacy of the conventional DCF regimen.

Apart from adjusting the dosage and frequency of medication, the renewal of drugs as well as the continuous optimization of different drug combinations have also become the critical research issues of nCT for EC. Nab-paclitaxel (Nab-PC), a new generation formulation of paclitaxel, has been used with cisplatin and has shown excellent performance in terms of the down-staging rate, R0 resection, and PCR rate [38]. S-1, developed in Japan, is a kind of oral fluorouracil alternative to infusional 5-FU and is considered effective and safe in treating patients with advanced SCC [15,39]. The cisplatin analogue nedaplatin has shown to be potentially active against SCC with reduced toxicity compared to cisplatin. The biweekly triple chemotherapy with docetaxel, 5-FU, and nedaplatin (UDON) has been proved to have good antitumor activity and tolerability. UDON has been evaluated as a first-line treatment for patients with advanced or recurrent SCC in Japan [40].

\section{Neoadjuvant Chemoradiotherapy}

In most Western countries, nCRT followed by esophagectomy has become a standard of care for patients with locally advanced resectable EC [41]. The largest multicenter RCT of nCRT compared with surgery alone was the Dutch CROSS (Chemoradiotherapy for Oesophageal Cancer Followed by Surgery Study) trial initiated in 2004. The CROSS trial randomized 366 patients between nCRT that consisted of carboplatin and paclitaxel for 5 weeks and concurrent radiotherapy (41.4 Gy in 23 fractions, 5 days per week) followed by surgery versus surgery alone. The multimodal therapy resulted in a pCR rate of $29 \%$ (49\% in SCC, $23 \%$ in AC), an R0 resection rate of $92 \%$, and a median survival time of 49.4 months, which were significantly higher than those in the surgery alone group. The long-term follow-up data also showed 3-, 5- and 10-year overall survival benefit, 14\%, 13\% and $13 \%$, respectively, indicating that the benefit for patients receiving nCRT lasts for at least 10 years [42]. Since then, the CROSS trial has solidified the foundation of nCRT in EC, which was consistent with the results of previous RCTs [43-48]. Although it is not difficult to conclude from the CROSS trial that the effects of nCRT on SCC seem larger than AC, it is hard to widely extrapolate this result because of the small fraction of SCC patients. The recently published NEOCRTEC5010 trial randomized 451 patients with SCC to receive either nCRT plus surgery or surgery alone [13]. The results showed that nCRT improved the 5-year survival compared to surgery alone group (59.9\% vs. 49.1\%, $p=0.025)$, which was more favorable than those of the CROSS trial [13]. Moreover, the R0 resection rate was higher in the nCRT group than surgery alone $(98.4 \%$ vs. $91.2 \%, p=0.002)$ and the pCR rate reached $43.2 \%$. Therefore, the nCRT may be considered as a practical approach for patients with locally advanced SCC. However, the results of the French FFCD9901 trial, which included 195 patients (70\% with SCC), showed that no significant difference between the $\mathrm{nCRT}$ and surgery arm regarding the R0 resection rate and 3-year survival [46]. Due to there being no benefit in both arms, the trial was stopped. A possible explanation might be that the FFCD9901 trial only included early-stage (fewer node-positive and T3 stage) patients 
and the perioperative mortality increased in the nCRT group. Therefore, these findings suggested that nCRT was not suitable for patients with an early clinical-stage tumor and offered an important reference to researchers about this treatment approach, although the results of the FFCD9901 trial were negative. The clinical trials mentioned above have been summarized in Table 3. Nevertheless, based on the effectiveness of perioperative chemotherapy for AC, several RCTs are ongoing to evaluate the optimal neoadjuvant therapy in patients with AC. The Neo-AEGIS trial is designed to further compare nCRT with the CROSS regimen versus the perioperative chemotherapy with modified MAGIC regimen (ECF/ECX or EOF/EOX) [49]. Moreover, considering the distinct advantage of the FLOT regimen in perioperative chemotherapy mentioned above $[50,51]$, the phase III randomized ESOPEC trial is developed to compare the FLOT-regimen-based perioperative chemotherapy versus CROSS-regimen-based nCRT [52]. The results of these trials will be bound to provide new evidence for the standard care in patients with locally advanced resectable $\mathrm{AC}$ in the near future.

Table 3. Clinical trials of neoadjuvant chemoradiotherapy versus surgery alone for locally advanced resectable EC.

\begin{tabular}{|c|c|c|c|c|c|c|c|c|c|c|c|}
\hline Trial & $\begin{array}{l}\text { Histologic } \\
\text { Subtype }\end{array}$ & TNM Stage & Intervention & Patients $(n)$ & CT & RT & $\begin{array}{l}\text { R0 } \\
(\%)\end{array}$ & $\begin{array}{l}\text { pCR } \\
(\%)\end{array}$ & $\begin{array}{c}\text { MST } \\
\text { (Months) }\end{array}$ & $\begin{array}{c}\text { OS (\%) } \\
(1 ; 2 ; 3 ; 4 ; 5 \text { Years) }\end{array}$ & $\begin{array}{l}\text { Postoperative } \\
\text { Mortality (\%) }\end{array}$ \\
\hline $\begin{array}{l}\text { Walsh, et al., } \\
1996[43]\end{array}$ & $\mathrm{AC}$ & NA & $\underset{\mathrm{S}}{\mathrm{nCRT} \rightarrow \mathrm{S}}$ & $\begin{array}{l}58 \\
55\end{array}$ & $\begin{array}{c}\mathrm{CF} \\
\text { (2 cycles) }\end{array}$ & $\begin{array}{l}40 \mathrm{~Gy} / 15 \\
\text { fractions }\end{array}$ & NA & $\begin{array}{l}25 \\
\text { NA }\end{array}$ & $\begin{array}{l}16 \\
11\end{array}$ & $\begin{array}{c}52 ; 37 ; 32 ;-;- \\
44 ; 26 ; 6 ;-;-\end{array}$ & $\begin{array}{l}3 \\
2\end{array}$ \\
\hline $\begin{array}{l}\text { CALGB } 9781 \\
2008[45]\end{array}$ & $\mathrm{AC}, \mathrm{SCC}$ & $\mathrm{T} 1-3, \mathrm{~N} 0-1$ & $\underset{\mathrm{S}}{\mathrm{nCRT} \rightarrow \mathrm{S}}$ & $\begin{array}{l}30 \\
26\end{array}$ & $\begin{array}{c}\mathrm{CF} \\
\text { (2 cycles) }\end{array}$ & $\begin{array}{l}50.4 \mathrm{~Gy} / 28 \\
\text { fractions }\end{array}$ & NA & $\begin{array}{r}40 \\
\text { NA }\end{array}$ & $\begin{array}{l}53.8 \\
21.5\end{array}$ & $\begin{array}{l}-;-;-;-; ; 39 \\
-;-; ;-; ; 16\end{array}$ & $\begin{array}{c}0 \\
4.2\end{array}$ \\
\hline $\begin{array}{l}\text { CROSS } \\
2012[9]\end{array}$ & $\mathrm{AC}, \mathrm{SCC}$ & $\begin{array}{c}\mathrm{T} 1, \mathrm{~N} 1 \text { or } \\
\mathrm{T} 2-3, \mathrm{~N} 0-1, \mathrm{M} 0\end{array}$ & $\underset{\mathrm{S}}{\mathrm{nCRT} \rightarrow \mathrm{S}}$ & $\begin{array}{l}178 \\
188\end{array}$ & $\begin{array}{c}\text { TC } \\
\text { (5 weeklycycles) }\end{array}$ & $\begin{array}{l}41.4 \mathrm{~Gy} / 23 \\
\text { fractions }\end{array}$ & $\begin{array}{l}92 \\
69\end{array}$ & $\begin{array}{l}29 \\
\mathrm{NA}\end{array}$ & $\begin{array}{l}49.4 \\
24.0\end{array}$ & $\begin{array}{l}82 ; 67 ; 58 ;-; 47 \\
70 ; 50 ; 44 ; ; ; 34\end{array}$ & $\begin{array}{l}4 \text { in hospital } \\
4 \text { in hospital }\end{array}$ \\
\hline $\begin{array}{l}\text { FFCD } 9901 \\
2014[46]\end{array}$ & $\mathrm{AC}, \mathrm{SCC}$ & $\begin{array}{l}\text { T1-2, N0-1, M0 } \\
\text { or T3, N0, M0 }\end{array}$ & $\underset{\mathrm{S}}{\mathrm{nCRT}} \rightarrow \mathrm{S}$ & $\begin{array}{l}98 \\
97\end{array}$ & $\begin{array}{c}\text { CF } \\
\text { (2 cycles) }\end{array}$ & $\begin{array}{l}45 \mathrm{~Gy} / 25 \\
\text { fractions }\end{array}$ & $\begin{array}{l}93.8 \\
92.1\end{array}$ & NA & $\begin{array}{l}31.8 \\
41.2\end{array}$ & $\begin{array}{l}-;-; 47.5 ;-; 41.1 \\
-;-; 53.0 ;-; 33.8\end{array}$ & $\begin{array}{l}11.1 \text { in hospital } \\
3.4 \text { in hospital }\end{array}$ \\
\hline $\begin{array}{c}\text { NEOCRTEC } \\
50102018 \\
{[13,53]}\end{array}$ & $\mathrm{SCC}$ & $\begin{array}{l}\mathrm{T} 1-4, \mathrm{~N} 1, \mathrm{M} 0 \\
\text { or T4, N0, M0 }\end{array}$ & $\begin{array}{c}\mathrm{nCRT} \rightarrow \mathrm{S} \\
\mathrm{S}\end{array}$ & $\begin{array}{l}224 \\
227\end{array}$ & $\begin{array}{c}\mathrm{VP} \\
\text { (2 cycles) }\end{array}$ & $\begin{array}{l}40 \mathrm{~Gy} / 20 \\
\text { fractions }\end{array}$ & $\begin{array}{l}98.4 \\
91.2\end{array}$ & $\begin{array}{c}43.2 \\
0\end{array}$ & $\begin{array}{c}100.1 \\
66.5\end{array}$ & $\begin{array}{l}90.0 ; 75.1 ; 69.1 ;-; 59.9 \\
86.2 ; 72.5 ; 58.9 ;-; 49.1\end{array}$ & $\begin{array}{l}2.2 \\
0.4\end{array}$ \\
\hline
\end{tabular}

RT, radiotherapy; $\mathrm{pCR}$, pathological complete response; $\mathrm{nCRT}$, neoadjuvant chemoradiotherapy; TC, paclitaxel/carboplatin; VP, vinorelbine/cisplatin.

However, with the emerging findings regarding the neoadjuvant interventions, many controversies remain, such as optimizing more effective nCRT protocols and surveillance strategies post-nCRT, and better patient selection for nCRT and surgery. In the following paragraphs, we focus on the research progress addressing these existing problems.

\subsection{Comparison between the Treatment Protocols of $n C R T$}

Based on the JCOG9204 and JCOG9907 trial results, nCT with CF regimen is a standard treatment for patients with cStage II/III SCC in Japan. In Western countries, the OEO2 RCT was carried out, in which $66 \%$ of patients with AC also showed a survival advantage in the neoadjuvant CF regimen group. In comparison, the CROSS trial has been proved to provide the maximum ever seen survival benefits for patients with esophageal or junctional cancer and has defined a new benchmark for the benefits from nRCT. Of note, using carboplatin and paclitaxel instead of the traditional CF regimen is one major innovation in the CROSS trial [2]. However, other trials also cast doubt on treating the CROSS regimen as the standard of care. A retrospective review showed higher rates of $\mathrm{pCR}$ and improved recurrence-free and OS in EC patients who completed nRCT with CF regimen compared to the CROSS regimen [54]. In addition, although the FLOT-4 trial revealed comparable 3-year survival in the docetaxel-based triplet regimen group with AC in the subgroup of the CROSS trial, the FLOT regimen is more simplified and less toxic. Therefore, prospective direct comparison RCTs involving direct comparisons are necessary to evaluate the relative merits of different chemotherapy options.

Another treatment strategy that has been a common concern is the induction of chemotherapy before nCRT and surgery. A multicenter phase II RCT (NCCTG N0849) evaluated the effect of adding induction chemotherapy prior to nCRT in EC patients [55]. Induction chemotherapy consisted of docetaxel $\left(60 \mathrm{mg} / \mathrm{m}^{2}\right.$, day 1$)$, oxaliplatin $\left(85 \mathrm{mg} / \mathrm{m}^{2}\right.$, day1), and capecitabine $\left(625 \mathrm{mg} / \mathrm{m}^{2}\right.$, day 1-14) every 21 days for two cycles followed by nCRT with 5FU, oxaliplatin, plus concurrent daily radiation (50.4 Gy in 28 fractions). The primary endpoint of this study was the pCR rate, and secondary endpoints included OS and disease- 
free survival (DFS). A total of 8 of 28 (28.6\%) patients that underwent induction chemotherapy had pCR versus $40.7 \%$ of patients that underwent nCRT followed by surgery $(p=0.34$ ). Given no statistical differences between the two groups, the trial was terminated, but the patients were followed. However, after a median follow-up of 60.4 months, a separation in OS was unexpectedly observed favoring the patients treated with induction chemotherapy over no induction (3-year survival rates $57.1 \%$ vs. $41.7 \%$ ). Moreover, induction (versus no induction) chemotherapy was associated with longer OS and DFS, particularly among patients with well/moderately differentiated tumors. Consistently, several recent studies also indicated that the intensification of preoperative cytotoxic chemotherapy brings no benefit to unselected patients with non-metastatic EC, indicating that other approaches are supposed to be considered to improve survival outcomes $[29,56]$. Future prospective evaluation trials should focus on the novel induction therapy (e.g., immunotherapy plus chemotherapy) that can improve OS and risk-stratification based on tumor differentiation by modern strategy (e.g., FDG-PET).

Going back to the aforementioned CROSS trial, another major innovation was the use of a lower neoadjuvant radiation dose (41.4 Gy in 23 fractions) instead of the standard dose (50.4 Gy in 25-28 fractions). To our knowledge, no converse data have exhibited inferior outcomes of $41.4 \mathrm{~Gy}$ in the nCRT process. As we know, higher radiation doses produce potentially better tumor control, but also expose patients to increased risks according to the sigmoidal curve for cell kill versus radiation dose in principle of radiation biology. A retrospective study from the USA using the National Cancer Data Base (NCDB) showed that a high neoadjuvant radiation dose is associated with an increased pCR rate $(p<0.001)$ and 30-day mortality, but with no difference in OS [57]. Considering the risk of complications, such as cardiac toxicity and radiation pneumonitis, a relatively lower neoadjuvant dose was recommended. Several groups recently demonstrated that although a lower radiation dose may result in slightly lower pCR rates (not significantly statistical difference) versus a high radiation dose, it did not affect the oncological outcomes [57-59]. Moreover, how to regulate the radiation dose for patients who drop out from neoadjuvant to definitive radiation therapy is another issue of concern. Therefore, prospective evaluation is of great value and should be designed with caution.

\subsection{Active Surveillance in Patient Post-nCRT with Complete Response}

Given that a substantial fraction of patients receiving nCRT reached pCR [2,9], it is reasonable to reconsider the necessity of surgical resection in those patients who respond sufficiently to nCRT. An active surveillance approach in which patients achieved a clinically complete response (cCR) after nCRT are subjected to serial clinical investigations; surgery was only offered to patients with loco-regional regrowth/residual disease. Similar approaches have been proved with curative results in several types of malignancy, including rectal, prostate, and head and neck cancer [60-62]. Therefore, the feasibility and efficacy of an active surveillance approach has been recently evaluated in patients with resectable EC after the completion of nCRT in different study designs [63-69]. The Germany Stahl et. al., France FFCD9102, and Korean ESOPRESSO trials are phase-III RCTs aiming to compare the clinical outcomes in complete responders to nCRT in EC. The primary outcome of the European trials is OS, while the Korean trial used DFS as the primary outcome. All published results are summarized in Table 4. Notably, the intervention arm (active surveillance plus surgery as needed) exhibits no relevant difference regarding OS in all three RCTs compared to the control arm (surgery on principle); only the ESOPRESSO trials showed decreased DFS, which might be due to the frequent local recurrence during surveillance [63-66]. In fact, early identification of resectable local recurrence without simultaneous distant dissemination is more critical than DFS itself. In order to establish the optimal combination of diagnostic techniques for clinical response evaluations (CRE) after nCRT, a prospective preSANO trial was designed and has already been completed at multicenters in the Netherlands [70]. The primary endpoint was the association of clinical response with the final pathological response, as shown by the proportion of tumor regression grade 
(TRG) 3 or 4 ( $>10 \%$ residual carcinoma in the resection specimen) tumors that went missing during CRE process. The results showed that 31\% (95\% CI 17-50) of TRG3/4 residual tumors went missing by endoscopy with regular biopsies and fine-needle aspiration (FNA), 10\% (95\% CI 4-23) went missing by bite-on-bite biopsies and FNA, 28\% (95\% CI 17-44) went missing by endoscopic ultrasonography (EUS) plus FNA, and 15\% (95\% CI 7-28) went missing by PET-CT. These findings provided the optimal combination of diagnostic modalities of CRE after nCRT in EC patients, which consisted of EUS, bite-on-bite biopsies, and FNA of suspicious lymph nodes for the detection of locoregional residual disease, with PET-CT for the detection of interval metastases. This combination of diagnostic tests helps to stratify the patients who might benefit from active surveillance 4-6 weeks after nCRT and is now being assessed in a phase III RCT (SANO trial). Apart from the Netherlands SANO trial, France ESOSTRATE and Chinese CELAEC are ongoing RCTs investigating the issue of active surveillance in patients with complete response after nCRT [68,69]. Consistent with the results of complete RCTs, retrospective cohort studies have shown the feasibility and non-inferiority of a non-surgical approach strategy in patients without compromising OS rates [71,72]. Van der Wilk et al. reported that patients with cCR undergoing active surveillance or surgery on principle had a 3-year OS of 77\% and 55\%, respectively (HR 0.41; 95\% CI 0.14-1.20, $p=0.104)$, and an equal distant dissemination rate (28\%) [73]. Similar results regarding the median OS in the active surveillance group versus surgery on principle are reported by Furlong et al. (55 months vs. 56 months in elderly patients) and Taketa et al. (57.9 months vs. 50.8 months) [72,74].

Table 4. Summary of randomized trials of surveillance vs. surgery in clinically complete responses after nCRT.

\begin{tabular}{|c|c|c|c|c|c|c|c|c|c|c|}
\hline RCTs & Histologic Subtype & TNM Stage & $\begin{array}{l}\text { Intervention after } \\
\text { CRT }\end{array}$ & $\begin{array}{l}\text { Patients } \\
\quad(n)\end{array}$ & $\begin{array}{l}\text { R0 } \\
(\%)\end{array}$ & $\begin{array}{c}\text { pCR (\%) } \\
\text { (S Group) }\end{array}$ & $\begin{array}{l}\text { DFS }(\%) \\
\text { (2 Years) }\end{array}$ & $\begin{array}{c}\text { MST } \\
\text { (Months) }\end{array}$ & $\begin{array}{c}\text { OS (\%) } \\
(2 ; 3 \text { Years) }\end{array}$ & $\begin{array}{l}\text { Postoperative } \\
\text { Mortality (\%) }\end{array}$ \\
\hline $\begin{array}{l}\text { Stahl, et al., } \\
2005[63]\end{array}$ & $\mathrm{SCC}$ & $\begin{array}{c}\text { T3-4, } \\
\text { N0-1, M0 }\end{array}$ & $\begin{array}{l}\text { A } \\
\text { S }\end{array}$ & $\begin{array}{l}86 \\
86\end{array}$ & 82 & 35 & NA & $\begin{array}{l}14.9 \\
16.4\end{array}$ & $\begin{array}{l}35.4 ; 24.4 \\
39.9 ; 31.3\end{array}$ & $\begin{array}{c}3.5 \\
12.8\end{array}$ \\
\hline $\begin{array}{c}\text { FFCD 9102 } \\
2006[64] \\
\& 2007[65]\end{array}$ & $\mathrm{SCC}, \mathrm{AC}$ & $\begin{array}{c}\mathrm{T} 3, \\
\mathrm{~N} 0-1, \mathrm{M} 0\end{array}$ & $\begin{array}{l}\text { A } \\
\text { S }\end{array}$ & $\begin{array}{l}130 \\
129\end{array}$ & $\mathrm{NA}$ & NA & NA & $\begin{array}{l}19.3 \\
17.7\end{array}$ & $\begin{array}{l}39.8 ;- \\
33.6 ;-\end{array}$ & $\begin{array}{l}0.8 \\
9.3\end{array}$ \\
\hline $\begin{array}{l}\text { ESOPRESSO } \\
2019[66]\end{array}$ & SCC & $\begin{array}{c}\text { cT3-T4a, } \\
\text { any N, M0 } \\
\text { or any T, } \\
\mathrm{N}+, \mathrm{M} 0\end{array}$ & $\begin{array}{l}\text { A } \\
\text { S }\end{array}$ & $\begin{array}{l}18 \\
19\end{array}$ & $\begin{array}{l}50.0 \\
92.3\end{array}$ & 69 & $\begin{array}{l}42.7 \\
66.7\end{array}$ & Not reached & $\begin{array}{l}\text { Not } \\
\text { reached }\end{array}$ & $\begin{array}{c}0 \\
5.3\end{array}$ \\
\hline
\end{tabular}

TC, paclitaxel/carboplatin; VP, vinorelbine/cisplatin

In conclusion, post-nCRT surveillance and surgery as needed are feasible for patients who reach cCRs without compromising OS. Although the benefit of active surveillance strategy has been investigated via different study designs, the currently available results were based on different protocols of neoadjuvant treatment and surveillance strategies. Therefore, there is an urgent need to perform high-quality RCTs regarding an active surveillance strategy for EC.

\section{Neoadjuvant Chemotherapy Versus Chemoradiotherapy}

As mentioned above, nCT and nCRT have been proved to bring a more significant survival benefit than surgery alone for patients with locally advanced resectable EC. However, according to the previous evidence-based findings and current guidelines, nCRT did not show an advantage over $\mathrm{nCT}$, which means the optimal treatment strategy remains controversial. As shown in Table 5, three RCTs, three RCTs directly compared the outcomes of nCRT versus nCT followed by surgery in EC. In the POET trial, patients with locally advanced EGJAC treated with nCRT showed a significantly higher pCR rate $(15.6 \%$ vs. $2 \%)$ and tumor-free lymph nodes $(64.4 \%$ vs. $27.7 \%)$. In spite of the fact that the nCRT arm showed a large but statistically insignificant trend toward 3-year survival benefit, the long-term results still suggested a superiority in local progression-free survival (PFS) to nCT arm $[75,76]$. Consistent with the observations in the POET trial, higher tumor response (histological complete response rate and R0/R1 resection rate) was also favored by nCRT arm in both the Neo-Res and Australian trial, which were larger completed multicenter RCTs [11,12,77]. However, paradoxically, such a tumor response was not translated to survival advantages. One possible explanation for the lack of survival benefit based on 
good tumor response in the nCRT group could be that the extensive lymph node dissection was used (lymph node dissection was practiced in $48 \%$ of patients with tumor resection in POET trial, $83 \%$ in Neo-Res and $100 \%$ in Australian trial). On the other hand, the Neo-Res trial defined $\mathrm{pCR}$ as a complete histologic response only in resected tumor tissue; in fact, residual tumor was found in lymph nodes in $10 \%$ of patients. In addition, given that the common recurrence pattern of AC was distant metastases, no survival benefit of the Australian trial might be attributed to the small number of $\mathrm{AC}$ patients who were diagnosed with stage II tumors and received low-intensity chemotherapy.

Table 5. Clinical trials of neoadjuvant chemoradiotherapy versus chemotherapy for locally advanced resectable EC.

\begin{tabular}{|c|c|c|c|c|c|c|c|c|c|c|c|}
\hline RCTs & $\begin{array}{c}\text { Histologic } \\
\text { Subtype }\end{array}$ & TNM Stage & $\begin{array}{l}\text { Intervention } \\
(n)\end{array}$ & СT & RT & $\begin{array}{l}\mathrm{R} 0 \\
(\%)\end{array}$ & $\begin{array}{l}\text { pCR } \\
(\%)\end{array}$ & $\begin{array}{c}\text { PFS } \\
\text { (3; } 5 \text { Years) } \\
(\%)\end{array}$ & $\begin{array}{c}\text { MST } \\
\text { (Months) }\end{array}$ & $\begin{array}{c}\text { OS } \\
(3 ; 5 \text { Years) } \\
(\%)\end{array}$ & $\begin{array}{l}\text { Postoperative } \\
\text { Mortality (\%) }\end{array}$ \\
\hline $\begin{array}{l}\text { Burmeister, } \\
\text { et al., } 2011 \text { [11] }\end{array}$ & $\mathrm{AC}$ & $\begin{array}{l}\text { cT2-3, } \\
\text { cN0-1 }\end{array}$ & $\begin{array}{c}\mathrm{nCRT} \rightarrow \mathrm{S}(39) \\
\mathrm{nCT} \rightarrow \mathrm{S}(36)\end{array}$ & $\begin{array}{c}\mathrm{CF} \\
\text { (2 cycles) }\end{array}$ & $35 \mathrm{~Gy} / 15$ fractions & $\begin{array}{l}84.6 \\
80.5\end{array}$ & $\begin{array}{c}13 \\
0\end{array}$ & NA & $\begin{array}{l}32 \\
29\end{array}$ & $\begin{array}{l}52 ; 45 \\
49 ; 36\end{array}$ & $\begin{array}{l}0 \\
0\end{array}$ \\
\hline $\begin{array}{c}\text { POET } \\
2009 \text { [75] and } \\
2017[76]\end{array}$ & $\mathrm{AC}$ & $\begin{array}{c}\text { T3-4, } \\
\text { Nx, M0 }\end{array}$ & $\begin{array}{c}\mathrm{nCRT} \rightarrow \mathrm{S}(60) \\
\mathrm{nCT} \rightarrow \mathrm{S}(59)\end{array}$ & $\begin{array}{l}\text { PLF ( } 2 \text { cycles }) \\
\text { +CE (1 cycles) } \\
\text { PLF( } 2.5 \text { cycles })\end{array}$ & 30Gy/15 fractions & $\begin{array}{l}72.0 \\
69.5\end{array}$ & $\begin{array}{c}15.6 \\
2.0\end{array}$ & NA & $\begin{array}{l}30.8 \\
21.1\end{array}$ & $\begin{array}{l}46.7 ; 39.5 \\
26.1 ; 24.4\end{array}$ & $\begin{array}{c}10.2 \\
3.8\end{array}$ \\
\hline $\begin{array}{c}\text { Neo-Res } \\
2016 \text { [77] and } \\
2019[12]\end{array}$ & $\begin{array}{c}\mathrm{AC}(75 \%) \\
\text { SCC }\end{array}$ & $\begin{array}{c}\text { T1-3, } \\
\text { any N } \\
\text { (except T1N0) }\end{array}$ & $\begin{array}{c}\mathrm{nCRT} \rightarrow \mathrm{S}(90) \\
\mathrm{nCT} \rightarrow \mathrm{S}(91)\end{array}$ & $\begin{array}{c}\mathrm{CF} \\
\text { (3 cycles) }\end{array}$ & $40 \mathrm{~Gy} / 20$ fractions & $\begin{array}{l}87 \\
74\end{array}$ & $\begin{array}{c}28 \\
9\end{array}$ & $\begin{array}{c}44 ; 38.9 \\
44 ; 33\end{array}$ & $\begin{array}{c}31.4 \\
36\end{array}$ & $\begin{array}{l}47 ; 42.2 \\
49 ; 39.6\end{array}$ & $\begin{array}{l}58 \\
60\end{array}$ \\
\hline
\end{tabular}

TC, paclitaxel/carboplatin; VP, vinorelbine/cisplatin.

A recent meta-analysis of eight RCTs involving 1030 patients with resectable EC was published to provide clinical evidence for comparing nCRT with nCT. This study reported a benefit of nCRT over nCT in OS (HR, 0.78,95\% CI 0.62-0.99, $p=0.04$ ), 5-year survival rate (RR 1.48, 95\% CI 1.06-2.07, $p=0.02$ ), pCR (RR 3.74, 95\% CI 2.03-6.88, $p<0.01$ ) and R0 resection rate (RR 1.13, 95\% CI 1.07-1.20, $p<0.01$ ), while the benefit was not associated with the risk of 30-day postoperative or in-hospital mortality [78]. For the first time, this study provided high-quality evidence to confirm the survival superiority of the use of nCRT over $\mathrm{nCT}$ in resectable EC; however, several limitations exist. It was a retrospective study including limited centers with diverse patient characteristics and therapy approaches, so further prospective studies in boarder populations are necessary.

The currently ongoing RCTs with larger numbers of patients primarily try to answer two questions. The first is whether nCRT has survival advantages over nCT; the second is whether the more appropriate chemoradiotherapy could improve clinical effects and minimize the adverse events. The Neo-AEGIS trial randomized 594 patients with ACs of esophagus or EGJ between pre- and post-operative chemotherapy with MAGIC or FLOT regimen versus nCRT with CROSS regimen [49]. The NeXT trial included a total of 501 patients with SCC who were randomized to nCT arm with CF or DCF regimens and nCRT arm with CF plus 41.4Gy radiation [79]. Moreover, immunotherapy has gained promising clinical benefits in neoadjuvant therapy, suggesting that the personalized combination of immunotherapy and chemoradiotherapy should be further investigated to improve the treatment effects.

\section{New Dimensions in Neoadjuvant Therapy for EC}

\subsection{Molecular Targeted Therapy Combined with $n C T$ or $n C R T$}

SCC is a deadly disease with a low 5-year survival rate, which requires multidisciplinary treatment. In recent years, targeted sequencing technologies have been developing at a fast speed. As a result, molecularly targeted therapies have been gradually applied to neoadjuvant therapy for $\mathrm{EC}$, but the results varied.

Epidermal growth factor (EGFR) is an important biomarker for predicting the outcome of SCC treatment. It has been reported that EGFR signaling pathway plays a crucial role in the growth, proliferation, invasion, and apoptosis of EC cells, and upregulated EGFR can be observed in most EC patients [80-83]. Therefore, the combination of neoadjuvant therapy with anti-EGFR agents may be a potential method to further improve the clinical efficacy. A prospective multicenter phase IB/II trial (SAKK 75/06) harbored the idea that cetuximab in combination with nCRT (DTX/CDDP + 45Gy RT) helped to improve the 
R0 resection and pCR rate without toxicity for patients with resectable locally advanced EC [84]. However, Ruhstaller et al. [53] continued to conduct a randomized open-label phase III trial (SAKK 75/08), which included a total of 300 patients. Despite the benefit patients have got from targeted therapis in the median PFS and median OS, this trial demonstrated that adding little or no cetuximab to nCRT yielded a higher R0 resection and pCR rate. Similar negative results were also observed in another clinical study. Preoperative cetuximab combination with nCRT (CPT-11/CDDP + 50.4Gy RT) not only exhibited no significant improvement in $\mathrm{pCR}$ rates for patients with locally advanced $\mathrm{AC}$ but could also lead to severe toxic and side effects [85]. In addition, the survival benefit of cetuximab added to nCRT remained disappointing in the RTOG-0436 and Scope- 1 trials [86,87]. As can be seen from these clinical trials, the efficacy of cetuximab in EC is still controversial and even contradictory.

Nimotuzumab (nimo) is kind of a recombinant humanized IgG monoclonal antibody, which finally inhibits the EGFR signaling pathway by effectively blocking the binding of EGF and transforming growth factor- $\alpha$ (TGF $\alpha$ ) [88]. According to a basic in vitro study, nimo promotes EC cells' radiosensitivity by upregulating the expression of IGFBP-3 [89]. Jing et al. argued that nimo in combination with nCRT appears to show more potential than cetuximab in treating locally advanced ESCC [90]. Nimo improved the disease control rate (DCR) (79.7 vs. $73.9, p=0.04)$ and significantly prolonged PFS (19.6 months vs. 13.0 months, $p=0.02$ ) without causing grade 3 or even more serious toxicity. The cheerful results on the treatment response and survival condition of nimo will be supportive to its further clinical study. Chen et al. enrolled 195 patients with locally advanced thoracic ESCC in a retrospective study to make a comparison between nimo-nCRT, nCRT alone (CF + 40Gy RT), and $\mathrm{nCT}$ alone (CF). The results showed that the addition of monoclonal antibodies was safe, the R0 resection rate reached $100 \%$, and the $\mathrm{pCR}$ rate reached $41.2 \%$. Compared with $\mathrm{nCRT}$ and $\mathrm{nCT}$ alone, the $\mathrm{R} 0$ resection and $\mathrm{pCR}$ rate, respectively, increased by $4.1 \%$ and $7.4 \%$, and $8.8 \%$ and $26.4 \%$ [91]. In another phase I study, Qi et al. [92] concluded that nimo combined with nCT (paclitaxel/carboplatin + 41.4Gy RT) had a favorable anti-cancer effect in locally resectable advanced EC with tolerable toxicities. Although the results from the above works are encouraging, it should be noted that the sample size is still limited, and the results cannot obtain further confirmation. For this reason, a large, multicenter, randomized phase III trial (NCT02409186) is underway to examine the efficacy of nCRT in combination with nimo in locally advanced SCC [93]. With the increasing clinical use of nimo, its drug resistance has gradually been discovered and significantly cut down on the available options for patients with EC. Sun et al. [94] published a case report of a patient who eventually developed nimotuzumab resistance after receiving multidisciplinary treatment with immune checkpoint inhibitors followed by nimo combined with chemotherapy (nab-paclitaxel, TN regimen). They suggested that the underlying mechanism of nimo resistance stems from the activation of the PI3K/AKT/mTOR pathway by discovering PIK3CA mutation and RICTOR amplification in the next-generation sequencing (NGS) assay. POWER was an open-label phase III superiority trial [95]. In this study, Moehler's research team held the view that another EGFR inhibitor pa-nitumumab was not beneficial to OS in patients with metastatic SCC. Moreover, a prospective analysis of predictive and prognostic serum and tumor tissue biomarkers reaped further insights into EGFR signaling pathways. Contrary to previous studies, the POWER trial indicated that EGFR expression was neither correlated with clinical parameters nor patients' prognostic outcomes. Last but not least, the team found that panitumumab induced the release of sEGFR, which turned out to be a negative factor triggering worse PFS. Consequently, the role of sEGFR in anti-EGFR therapies needs clearer explanation and further detection.

In addition to the EGFR signaling pathway, multitudes of studies are carried out to make contributions to the diversity of molecular targeted therapies in EC. The vascular endothelial growth factor (VEGF) inhibitor bevacizumab was added to perioperative ECX chemotherapy in the ST03 trial, but the results were not optimistic enough [96]. Another two phase-II clinical trials centered on human epidermal growth factor receptor 2 (HER2) 
and investigated the addition of trastuzumab to perioperative treatment. They successfully reached the consensus that neoadjuvant targeted therapy helped more patients to obtain pCR and led to a higher R0 resection rate $[97,98]$. Present and future randomized trials are trying to combine targeted monoclonal antibodies with classic $\mathrm{nCT}$ and $\mathrm{nCRT}$ regimens (CROSS, FLOT, et al.) that have been proven to offer clear clinical advantages [17]. The results of these trials are highly expected by everyone.

\subsection{Immunotherapy with Checkpoint Inhibitors Combined with $n C T$ or $n C R T$}

Antibody-based immunotherapy, adoptive cell therapy, and vaccine-based immunotherapy yielded great fruits in improving outcomes of tumors. Among them, the birth of immune checkpoint inhibitors (ICIs) opened a new era for the treatment of EC. With the increasing related research, the overexpression of programmed cell ligand-1 (PD-1) has been found to be widely involved in the process of immune evasion, which has a lot to do with EC patients' adverse pathological response and dreadful prognosis [99-101]. Nivolumab and pembrolizumab are two main types of PD-1 ICIs, whose mechanism is to block the immunosuppressive action of ligand, which is of great help for the body's immune system to clear tumor cells from the body. In 2019, pembrolizumab was approved by the FDA as a second-line treatment for PD-1-positive patients [102]. In a multi-cohort Phase IB study (KEYNOTE-028), the overall response rate for 23 PD-1-positive SCC and EGJ patients was 30\% and the median duration of response reached 15 months [103]. Furthermore, KEYNOTE-181 aimed to evaluate the anti-tumor activity of pembrolizumab as a second-line therapy compared with chemotherapy alone. This work fully proved prolonged median OS (9.3 vs. 6.7 months) and acceptable toxicity in the mAb group [104]. Nivolumab is human IGG4 ICI preventing anti-tumor T cells' inactivation. In 2019, Kato et al. [99] implemented the ATTRACTION-3 trial to carry out a final analysis of nivolumab's curative effect for patients with advanced ESCC refractory or intolerance to the former chemotherapy regimen. They concluded that compared with chemotherapy (paclitaxel or docetaxel), nivolumab possessed a better survival benefit and showed a better safety property. Moreover, Japan has approved nivolumab as a second-line immunotherapy for advanced unresectable or recurrent EC since 2020 [105].

This year, Shen et al. [106] administered 28 patients with resectable locally advanced ESCC to evaluate the feasibility and safety of a neoadjuvant treatment protocol of PD-1 ICIs (pembrolizumab: $2 \mathrm{mg} / \mathrm{kg}$, nivolumab: $3 \mathrm{mg}$, camrelizumab: $200 \mathrm{mg}$ ) combined with nCT (albumin paclitaxel + carboplatin). This regimen produced an unprecedentedly high R0 resection and PCR rate. More importantly, researchers had new discoveries. For one thing, after this innovative neoadjuvant regimen, tumors tended to adhere to the surrounding tissues more loosely, which permitted easier resection in surgery. For another, no pseudoprogression was observed in this trial. Despite all of these positive findings, it is still uncertain what the optimum number of neoadjuvant therapy cycles is, and there is an urgent need to identify predictive biomarkers to help scientists examine the effect of immunotherapy precisely with the aim of determining the best subsequent treatment options. To address the problems, Wu et al. [107] investigated the expression of immunorelated molecules and held the view that the expression of the sum of lesion diameter (SLD) was positively associated with the pathological remission rate of EC to a significant extent. Moreover, evidence from the PERFECT-trial suggested that it is promising to explore the IFN- $\gamma$ signature and baseline combined positivity score (CPS) for PD-L1 as potential biomarkers [108]. These scientific works have exerted a profound impact on future immunotherapy for EC patients.

Immunotherapy combined with nCRT has been proven to potentiate a synergistic effect. Local radiotherapy increases T-cell infiltration and antigen presentation, sup-porting immune-mediated out-of-field (abscopal) effects [109-111]. Achievements of a phase III trial (CheckMate577) have been reported at the 2021 ASCO meeting. This study supports that DFS and distant metastasis-free survival (DMFS) were significantly longer among patients who received nCRT followed by nivolumab [112]. However, a large multi-center 
or multi-ethnic study is still required to further evaluate the safety and efficacy of nCRT combined with immunotherapy in resectable EC.

In the end, with the development of immunotherapy, several key questions remain to be taken into consideration. On the one hand, the central premise of cancer immunotherapy is patients' certain degree of immunity to exert antitumoral properties. Consequently, the efficacy will be greatly reduced for patients with immunologic failure. On the other hand, a great many previous studies indicated that $\mathrm{nCT}$ and nCRT regimens could produce toxicity, which mainly leads to immunosuppression. Further studies are supposed to focus on developing more innovative ICIs and exploring how to maximize the therapeutic efficacy of immunotherapy.

\section{Conclusions}

Neoadjuvant therapy is an essential part of multi-modality treatments in patients with EC. It has become a research hotspot due to its high efficacy and diversified combination regimens. Compared with surgery alone, $\mathrm{nCT}$ and nCRT consistently improved survival condi-tions for either SCC or AC patients. However, controversies still exist. In this review, we focus on the research progress in investigating innovative chemotherapy regimens to reduce the incidence of serious complications and identify more effective nCRT protocols and post-nCRT active surveillance strategies. In addition, neoadjuvant immunotherapy and targeted therapy have shown excellent efficacy and bright development prospects, which provide more options. A multitude of clinical studies are currently ongoing in search of the best combination therapy. Hence, selecting suitable chemotherapeutic agents and the optimal radiotherapy strategy, screening the target population, and avoiding severe complications and adverse reactions are still important research directions of the future work in the field of EC. We believe that substantial breakthroughs will be made through more and more pro-spective RCTs in the near future.

Author Contributions: S.H. and Z.P. were involved in the writing and editing of the manuscript. Y.D. and Q.H. conceptualized the article. X.H. created the tables. All authors have read and agreed to the published version of the manuscript.

Funding: This work was supported in part by a grant from National Natural Science Foundation of China (No. 31800675 to S.H.) and the Postdoctoral Science Foundation in Jiangsu Province (No. 2018K263C to S.H.), the Key Project for Social Development in Jiangsu Province (BE-2019698), the Strengthening Health Care via Science and Education Project and Clinical Medical Innovation Platform Foundation of Yangzhou (YXZX20184), and the Major Public Health Projects in Yangzhou: Screening projects of early gastrointestinal diseases (2018).

Conflicts of Interest: The authors declare that the research was conducted in the absence of any commercial or financial relationships that could be construed as a potential conflict of interest.

\section{References}

1. Sung, H.; Ferlay, J.; Siegel, R.L.; Laversanne, M.; Soerjomataram, I.; Jemal, A.; Bray, F. Global Cancer Statistics 2020: GLOBOCAN Estimates of Incidence and Mortality Worldwide for 36 Cancers in 185 Countries. CA Cancer J. Clin. 2021, 71, 209-249. [CrossRef] [PubMed]

2. Shapiro, J.; van Lanschot, J.J.B.; Hulshof, M.C.C.M.; van Hagen, P.; van Berge Henegouwen, M.I.; Wijnhoven, B.P.L.; van Laarhoven, H.W.M.; Nieuwenhuijzen, G.A.P.; Hospers, G.A.P.; Bonenkamp, J.J.; et al. Neoadjuvant chemoradiotherapy plus surgery versus surgery alone for oesophageal or junctional cancer (CROSS): Long-term results of a randomised controlled trial. Lancet Oncol. 2015, 16, 1090-1098. [CrossRef]

3. Oppedijk, V.; van der Gaast, A.; van Lanschot, J.J.; van Hagen, P.; van Os, R.; van Rij, C.M.; van der Sangen, M.J.; Beukema, J.C.; Rütten, H.; Hulshof, M.C.; et al. Patterns of recurrence after surgery alone versus preoperative chemoradiotherapy and surgery in the CROSS trials. J. Clin. Oncol. 2014, 32, 385-391. [CrossRef]

4. Barkin, J. Perioperative Chemotherapy versus Surgery Alone for Resectable Gastroesophageal Cancer. Yearb. Med. 2007, 2007, 406-407. [CrossRef]

5. Allum, W.H.; Stenning, S.P.; Bancewicz, J.; Clark, P.I.; Langley, R.E. Long-Term Results of a Randomized Trial of Surgery with or Without Preoperative Chemotherapy in Esophageal Cancer. J. Clin. Oncol. 2009, 27, 5062-5067. [CrossRef] [PubMed] 
6. Ajani, J.A.; D’Amico, T.A.; Bentrem, D.J.; Chao, J.; Corvera, C.; Das, P.; Denlinger, C.S.; Enzinger, P.C.; Fanta, P.; Farjah, F.; et al. Esophageal and Esophagogastric Junction Cancers, Version 2.2019, NCCN Clinical Practice Guidelines in Oncology. J. Natl. Compr. Canc. Netw. 2019, 17, 855-883. [CrossRef]

7. Lordick, F.; Mariette, C.; Haustermans, K.; Obermannová, R.; Arnold, D. Oesophageal cancer: ESMO Clinical Practice Guidelines for diagnosis, treatment and follow-up. Ann. Oncol. 2016, 27, v50-v57. [CrossRef]

8. National Guideline Alliance (UK). Oesophago-Gastric Cancer: Assessment and Management in Adults; National Institute for Health and Care Excellence: London, UK, 2018. [CrossRef]

9. Van Hagen, P.; Hulshof, M.C.C.M.; Van Lanschot, J.J.B.; Steyerberg, E.W.; Henegouwen, M.V.B.; Wijnhoven, B.P.L.; Richel, D.J.; Nieuwenhuijzen, G.A.P.; Hospers, G.A.P.; Bonenkamp, J.J.; et al. Preoperative Chemoradiotherapy for Esophageal or Junctional Cancer. N. Engl. J. Med. 2012, 366, 2074-2084. [CrossRef]

10. Watanabe, M.; Otake, R.; Kozuki, R.; Toihata, T.; Takahashi, K.; Okamura, A.; Imamura, Y. Recent progress in multidisciplinary treatment for patients with esophageal cancer. Surg. Today 2020, 50, 12-20. [CrossRef] [PubMed]

11. Burmeister, B.H.; Thomas, J.M.; Burmeister, E.A.; Walpole, E.; Harvey, J.A.; Thomson, D.B.; Barbour, A.; Gotley, D.; Smithers, B.M. Is concurrent radiation therapy required in patients receiving preoperative chemotherapy for adenocarcinoma of the oesophagus? A randomised phase II trial. Eur. J. Cancer 2011, 47, 354-360. [CrossRef]

12. Von Döbeln, G.A.; Klevebro, F.; Jacobsen, A.-B.; Johannessen, H.-O.; Nielsen, N.H.; Johnsen, G.; Hatlevoll, I.I.; Glenjen, N.; Friesland, S.; Lundell, L.; et al. Neoadjuvant chemotherapy versus neoadjuvant chemoradiotherapy for cancer of the esophagus or gastroesophageal junction: Long-term results of a randomized clinical trial. Dis. Esophagus 2019, 32, doy078. [CrossRef]

13. Yang, H.; Liu, H.; Chen, Y.; Zhu, C.; Fang, W.; Yu, Z.; Mao, W.; Xiang, J.; Han, Y.; Chen, Z.; et al. Long-term Efficacy of Neoadjuvant Chemoradiotherapy Plus Surgery for the Treatment of Locally Advanced Esophageal Squamous Cell Carcinoma: The NEOCRTEC5010 Randomized Clinical Trial. JAMA Surg. 2021, 156, 721-729. [CrossRef] [PubMed]

14. Sohda, M.; Kuwano, H. Current Status and Future Prospects for Esophageal Cancer Treatment. Ann. Thorac. Cardiovasc. Surg. 2017, 23, 1-11. [CrossRef] [PubMed]

15. Van Der Wilk, B.J.; Eyck, B.M.; Lagarde, S.M.; Van Der Gaast, A.; Nuyttens, J.J.M.E.; Wijnhoven, B.P.L.; Van Lanschot, J.J.B. The optimal neoadjuvant treatment of locally advanced esophageal cancer. J. Thorac. Dis. 2019, 11, S621-S631. [CrossRef]

16. Mayanagi, S.; Irino, T.; Kawakubo, H.; Kitagawa, Y. Neoadjuvant treatment strategy for locally advanced thoracic esophageal cancer. Ann. Gastroenterol. Surg. 2019, 3, 269-275. [CrossRef] [PubMed]

17. Ende, T.V.D.; Smyth, E.; Hulshof, M.C.; Van Laarhoven, H.W. Chemotherapy and novel targeted therapies for operable esophageal and gastroesophageal junctional cancer. Best Pr. Res. Clin. Gastroenterol. 2018, 36-37, 45-52. [CrossRef]

18. Medical Research Council Oesophageal Cancer Working Group Surgical resection with or without preoperative chemotherapy in oesophageal cancer: A randomised controlled trial. Lancet 2002, 359, 1727-1733. [CrossRef]

19. Ychou, M.; Boige, V.; Pignon, J.-P.; Conroy, T.; Bouché, O.; Lebreton, G.; Ducourtieux, M.; Bedenne, L.; Fabre, J.-M.; Saint-Aubert, B.; et al. Perioperative Chemotherapy Compared with Surgery Alone for Resectable Gastroesophageal Adenocarcinoma: An FNCLCC and FFCD Multicenter Phase III Trial. J. Clin. Oncol. 2011, 29, 1715-1721. [CrossRef]

20. Fiteni, F.; Paget-Bailly, S.; Messager, M.; N'Guyen, T.; Lakkis, Z.; Mathieu, P.; Lamfichekh, N.; Picard, A.; Benzidane, B.; Cléau, D.; et al. Docetaxel, Cisplatin, and 5-Fluorouracil as perioperative chemotherapy compared with surgery alone for resectable gastroesophageal adenocarcinoma. Cancer Med. 2016, 5, 3085-3093. [CrossRef]

21. Ando, N.; Kato, H.; Igaki, H.; Shinoda, M.; Ozawa, S.; Shimizu, H.; Nakamura, T.; Yabusaki, H.; Aoyama, N.; Kurita, A.; et al. A Randomized Trial Comparing Postoperative Adjuvant Chemotherapy with Cisplatin and 5-Fluorouracil Versus Preoperative Chemotherapy for Localized Advanced Squamous Cell Carcinoma of the Thoracic Esophagus (JCOG9907). Ann. Surg. Oncol. 2011, 19, 68-74. [CrossRef]

22. Kelsen, D.P.; Winter, K.A.; Gunderson, L.L.; Mortimer, J.; Estes, N.C.; Haller, D.G.; Ajani, J.A.; Kocha, W.; Minsky, B.D.; Roth, J.A.; et al. Long-Term Results of RTOG Trial 8911 (USA Intergroup 113): A Random Assignment Trial Comparison of Chemotherapy Followed by Surgery Compared with Surgery Alone for Esophageal Cancer. J. Clin. Oncol. 2007, 25, 3719-3725. [CrossRef] [PubMed]

23. Hale, M.D.; Nankivell, M.; Hutchins, G.G.; Stenning, S.P.; Langley, R.E.; Mueller, W.; Guan, Z.; West, N.P.; Cunningham, D.; Grabsch, H.I.; et al. Biopsy proportion of tumour predicts pathological tumour response and benefit from chemotherapy in resectable oesophageal carcinoma: Results from the UK MRC OE02 trial. Oncotarget 2016, 7, 77565-77575. [CrossRef]

24. Sundar, R.; Ng, A.; Zouridis, H.; Padmanabhan, N.; Sheng, T.; Zhang, S.; Lee, M.H.; Ooi, W.F.; Qamra, A.; Inam, I.; et al. DNA epigenetic signature predictive of benefit from neoadjuvant chemotherapy in oesophageal adenocarcinoma: Results from the MRC OE02 trial. Eur. J. Cancer 2019, 123, 48-57. [CrossRef]

25. Ojima, T.; Nakamori, M.; Nakamura, M.; Katsuda, M.; Hayata, K.; Kato, T.; Kitadani, J.; Tabata, H.; Takeuchi, A.; Iwahashi, M.; et al. Neoadjuvant Chemotherapy with Divided-dose Docetaxel, Cisplatin and Fluorouracil for Patients with Squamous Cell Carcinoma of the Esophagus. Anticancer Res. 2016, 36, 829-834.

26. Hara, H.; Tahara, M.; Daiko, H.; Kato, K.; Igaki, H.; Kadowaki, S.; Tanaka, Y.; Hamamoto, Y.; Matsushita, H.; Nagase, M.; et al. Phase II feasibility study of preoperative chemotherapy with docetaxel, cisplatin, and fluorouracil for esophageal squamous cell carcinoma. Cancer Sci. 2013, 104, 1455-1460. [CrossRef] [PubMed] 
27. Satake, H.; Tahara, M.; Mochizuki, S.; Kato, K.; Hara, H.; Yokota, T.; Kiyota, N.; Kii, T.; Chin, K.; Zenda, S.; et al. A prospective, multicenter phase I/II study of induction chemotherapy with docetaxel, cisplatin and fluorouracil (DCF) followed by chemoradiotherapy in patients with unresectable locally advanced esophageal carcinoma. Cancer Chemother. Pharmacol. 2016, 78, 91-99. [CrossRef] [PubMed]

28. Yokota, T.; Ando, N.; Igaki, H.; Shinoda, M.; Kato, K.; Mizusawa, J.; Katayama, H.; Nakamura, K.; Fukuda, H.; Kitagawa, Y. Prognostic Factors in Patients Receiving Neoadjuvant 5-Fluorouracil plus Cisplatin for Advanced Esophageal Cancer (JCOG9907). Oncology 2015, 89, 143-151. [CrossRef]

29. Alderson, D.; Cunningham, D.; Nankivell, M.; Blazeby, J.M.; Griffin, S.M.; Crellin, A.; Thompson, J.; Falk, S.; Okines, A.; Langley, R.E.; et al. Neoadjuvant cisplatin and fluorouracil versus epirubicin, cisplatin, and capecitabine followed by resection in patients with oesophageal adenocarcinoma (UK MRC OE05): An open-label, randomised phase 3 trial. Lancet Oncol. 2017, 18, 1249-1260. [CrossRef]

30. Al-Batran, S.-E.; Homann, N.; Pauligk, C.; Goetze, T.O.; Meiler, J.; Kasper, S.; Kopp, H.-G.; Mayer, F.; Haag, G.M.; Luley, K.; et al. Perioperative chemotherapy with fluorouracil plus leucovorin, oxaliplatin, and docetaxel versus fluorouracil or capecitabine plus cisplatin and epirubicin for locally advanced, resectable gastric or gastro-oesophageal junction adenocarcinoma (FLOT4): A randomised, phase 2/3 trial. Lancet 2019, 393, 1948-1957. [CrossRef]

31. Barbour, A.P.; Walpole, E.T.; Mai, G.T.; Barnes, E.H.; Watson, D.I.; Ackland, S.P.; Martin, M.; Burge, M.; Finch, R.; Barnes, L.; et al. Preoperative cisplatin, fluorouracil, and docetaxel with or without radiotherapy after poor early response to cisplatin and fluorouracil for resectable oesophageal adenocarcinoma (AGITG DOCTOR): Results from a multicentre, randomised controlled phase II trial. Ann. Oncol. 2020, 31, 236-245. [CrossRef]

32. Yamasaki, M.; Yasuda, T.; Yano, M.; Hirao, M.; Kobayashi, K.; Fujitani, K.; Miyata, H.; Motoori, M.; Shiraishi, O.; Doki, Y.; et al. Multicenter randomized phase II study of cisplatin and fluorouracil plus docetaxel (DCF) compared with cisplatin and fluorouracil plus Adriamycin (ACF) as preoperative chemotherapy for resectable esophageal squamous cell carcinoma (OGSG1003). Ann. Oncol. 2017, 28, 116-120. [CrossRef] [PubMed]

33. Sugimura, K.; Yamasaki, M.; Yasuda, T.; Yano, M.; Hirao, M.; Fujitani, K.; Kimura, Y.; Miyata, H.; Motoori, M.; Takeno, A.; et al. Long-term results of a randomized controlled trial comparing neoadjuvant Adriamycin, cisplatin, and 5-fluorouracil vs docetaxel, cisplatin, and 5-fluorouracil followed by surgery for esophageal cancer (OGSG1003). Ann. Gastroenterol. Surg. 2021, 5, 75-82. [CrossRef]

34. Onitilo, A.A.; Stankowski-Drengler, T.J.; Shiyanbola, O.; Engel, J.; Tanimu, S.; Fagbemi, S.O.; Li, Y.-H. Modified Docetaxel, Cisplatin, and Fluorouracil (mDCF) as a Neoadjuvant Chemotherapy for Non-metastatic Esophageal Cancer (nMEC). Clin. Med. Res. 2021, 19, 64-71. [CrossRef]

35. Akiyama, Y.; Sasaki, A.; Endo, F.; Nikai, H.; Amano, S.; Umemura, A.; Baba, S.; Chiba, T.; Kimura, T.; Takahara, T.; et al. Outcomes of esophagectomy after chemotherapy with biweekly docetaxel plus cisplatin and fluorouracil for advanced esophageal cancer: A retrospective cohort analysis. World J. Surg. Oncol. 2018, 16, 122. [CrossRef]

36. Yokota, T.; Kato, K.; Hamamoto, Y.; Tsubosa, Y.; Ogawa, H.; Ito, Y.; Hara, H.; Ura, T.; Kojima, T.; Chin, K.; et al. Phase II study of chemoselection with docetaxel plus cisplatin and 5-fluorouracil induction chemotherapy and subsequent conversion surgery for locally advanced unresectable oesophageal cancer. Br. J. Cancer 2016, 115, 1328-1334. [CrossRef] [PubMed]

37. Watanabe, M.; Baba, Y.; Yoshida, N.; Ishimoto, T.; Nagai, Y.; Iwatsuki, M.; Iwagami, S.; Baba, H. Outcomes of Preoperative Chemotherapy with Docetaxel, Cisplatin, and 5-Fluorouracil Followed by Esophagectomy in Patients with Resectable NodePositive Esophageal Cancer. Ann. Surg. Oncol. 2014, 21, 2838-2844. [CrossRef] [PubMed]

38. Fan, Y.; Jiang, Y.; Zhou, X.; Chen, Q.; Huang, Z.; Xu, Y.; Liu, J.; Yang, H.; Yu, H.; Mao, W.; et al. Phase II study of neoadjuvant therapy with nab-paclitaxel and cisplatin followed by surgery in patients with locally advanced esophageal squamous cell carcinoma. Oncotarget 2016, 7, 50624-50634. [CrossRef]

39. Kanda, M.; Koike, M.; Iwata, N.; Shimizu, D.; Tanaka, C.; Hattori, N.; Hayashi, M.; Yamada, S.; Omae, K.; Nakayama, G.; et al. An Open-Label Single-Arm Phase II Study of Treatment with Neoadjuvant S-1 Plus Cisplatin for Clinical Stage III Squamous Cell Carcinoma of the Esophagus. Oncologist 2020, 25, e1650-e1654. [CrossRef] [PubMed]

40. Ueda, H.; Kawakami, H.; Nonagase, Y.; Takegawa, N.; Okuno, T.; Takahama, T.; Takeda, M.; Chiba, Y.; Tamura, T.; Nakagawa, K. Phase II Trial of 5-Fluorouracil, Docetaxel, and Nedaplatin (UDON) Combination Therapy for Recurrent or Metastatic Esophageal Cancer. Oncologist 2018, 24, 163-e76. [CrossRef]

41. Sato, Y.; Motoyama, S.; Wada, Y.; Wakita, A.; Kawakita, Y.; Nagaki, Y.; Terata, K.; Imai, K.; Anbai, A.; Hashimoto, M.; et al Neoadjuvant Chemoradiotherapy Followed by Esophagectomy with Three-Field Lymph Node Dissection for Thoracic Esophageal Squamous Cell Carcinoma Patients with Clinical Stage III and with Supraclavicular Lymph Node Metastasis. Cancers 2021, 13, 983. [CrossRef] [PubMed]

42. Eyck, B.M.; van Lanschot, J.J.B.; Hulshof, M.C.C.M.; van der Wilk, B.J.; Shapiro, J.; van Hagen, P.; Henegouwen, M.I.V.B.; Wijnhoven, B.P.L.; van Laarhoven, H.W.M.; Nieuwenhuijzen, G.A.P.; et al. Ten-Year Outcome of Neoadjuvant Chemoradiotherapy Plus Surgery for Esophageal Cancer: The Randomized Controlled CROSS Trial. J. Clin. Oncol. 2021, 39, 1995-2004. [CrossRef] [PubMed]

43. Walsh, T.N.; Noonan, N.; Hollywood, D.; Kelly, A.; Keeling, N.; Hennessy, T.P. A comparison of multimodal therapy and surgery for esophageal adenocarcinoma. N. Engl. J. Med. 1996, 335, 462-467. [CrossRef] [PubMed] 
44. Bosset, J.F.; Gignoux, M.; Triboulet, J.P.; Tiret, E.; Mantion, G.; Elias, D.; Ahmoud, A.S.; Lozach, P.; Ollier, J.-C.; Chaillard, G. J Chemoradiotherapy followed by surgery compared with surgery alone in squamous-cell cancer of the esophagus. N. Engl. J. Med. 1997, 337, 161-167. [CrossRef]

45. Tepper, J.; Krasna, M.J.; Niedzwiecki, D.; Hollis, D.; Reed, C.E.; Goldberg, R.; Kiel, K.; Willett, C.; Sugarbaker, D.; Mayer, R. Phase III Trial of Trimodality Therapy with Cisplatin, Fluorouracil, Radiotherapy, and Surgery Compared with Surgery Alone for Esophageal Cancer: CALGB 9781. J. Clin. Oncol. Off. J. Am. Soc. Clin. Oncol. 2008, 26, 1086-1092. [CrossRef]

46. Mariette, C.; Dahan, L.; Mornex, F.; Maillard, E.; Thomas, P.; Meunier, B.; Boige, V.; Pezet, D.; Robb, W.B.; Le Brun-Ly, V.; et al. Surgery Alone Versus Chemoradiotherapy Followed by Surgery for Stage I and II Esophageal Cancer: Final Analysis of Randomized Controlled Phase III Trial FFCD 9901. J. Clin. Oncol. 2014, 32, 2416-2422. [CrossRef] [PubMed]

47. Ruhstaller, T.; Thuss-Patience, P.; Hayoz, S.; Schacher, S.; Knorrenschild, J.R.; Schnider, A.; Plasswilm, L.; Budach, W.; Hawle, H.; Stahl, M.; et al. Neo-adjuvant chemotherapy followed by chemoradiation and surgery with and without cetuximab in patients with resectable esophageal cancer: A randomized, open-label, phase III trial (SAKK 75/08). Ann. Oncol. 2018, 29, 1386-1393. [CrossRef]

48. Bass, G.; Furlong, H.; O'Sullivan, K.; Hennessy, T.; Walsh, T. Chemoradiotherapy, with adjuvant surgery for local control, confers a durable survival advantage in adenocarcinoma and squamous cell carcinoma of the oesophagus. Eur. J. Cancer 2014, 50, 1065-1075. [CrossRef]

49. Reynolds, J.V.; Preston, S.R.; O'neill, B.; Baeksgaard, L.; Griffin, S.M.; Mariette, C.; Johnson, C.; Ravi, N.; Jones, G.; Mc Dermott, R.; et al. ICORG 10-14: NEOadjuvant trial in Adenocarcinoma of the oEsophagus and oesophagoGastric junction International Study (Neo-AEGIS). BMC Cancer 2017, 17, 401. [CrossRef]

50. Homann, N.; Pauligk, C.; Luley, K.; Kraus, T.W.; Bruch, H.-P.; Atmaca, A.; Noack, F.; Altmannsberger, H.-M.; Jäger, E.; Al-Batran, S.-E. Pathological complete remission in patients with oesophagogastric cancer receiving preoperative 5-fluorouracil, oxaliplatin and docetaxel. Int. J. Cancer 2012, 130, 1706-1713. [CrossRef] [PubMed]

51. Lorenzen, S.; Pauligk, C.; Homann, N.; Schmalenberg, H.; Jäger, E.; Al-Batran, S.-E. Feasibility of perioperative chemotherapy with infusional 5-FU, leucovorin, and oxaliplatin with (FLOT) or without (FLO) docetaxel in elderly patients with locally advanced esophagogastric cancer. Br. J. Cancer 2013, 108, 519-526. [CrossRef]

52. Hoeppner, J.; Lordick, F.; Brunner, T.; Glatz, T.; Bronsert, P.; Röthling, N.; Schmoor, C.; Lorenz, D.; Ell, C.; Hopt, U.T.; et al. ESOPEC: Prospective randomized controlled multicenter phase III trial comparing perioperative chemotherapy (FLOT protocol) to neoadjuvant chemoradiation (CROSS protocol) in patients with adenocarcinoma of the esophagus (NCT02509286). BMC Cancer 2016, 16, 1-10. [CrossRef] [PubMed]

53. Yang, H.H.L.; Chen, Y.; Zhu, C.; Fang, W.; Yu, Z.; Mao, W.; Xiang, J.; Han, Y.; Chen, Z.; Yang, H.; et al. Neoadjuvant Chemoradiotherapy Followed by SurgeryVersus Surgery Alone for Locally Advanced Squamous Cell Carcinoma of the Esophagus (NEOCRTEC5010): A Phase III Multicenter, Randomized, Open-Label Clinical Trial. J. Clin. Oncol. 2018, 36, 2796-2803. [CrossRef] [PubMed]

54. Haisley, K.R.; Hart, K.D.; Nabavizadeh, N.; Bensch, K.G.; Vaccaro, G.M.; Thomas, C.R., Jr.; Schipper, P.H.; Hunter, J.G.; Dolan, J.P. Neoadjuvant chemoradiotherapy with concurrent cisplatin/5-fluorouracil is associated with increased pathologic complete response and improved survival compared to carboplatin/paclitaxel in patients with locally advanced esophageal cancer. Dis. Esophagus 2017, 30, 1-7. [CrossRef] [PubMed]

55. Yoon, H.H.; Ou, F.S.; Soori, G.S.; Shi, Q.; Wigle, D.A.; Sticca, R.P.; Miller, R.C.; Leenstra, J.L.; Peller, P.J.; Alberts, S.R.; et al. Induction versus no induction chemotherapy before neoadjuvant chemoradiotherapy and surgery in oesophageal adenocarcinoma: A multicentre randomised phase II trial (NCCTG N0849 [Alliance]). Eur. J. Cancer 2021, 150, 214-223. [CrossRef]

56. Ajani, J.A.; Xiao, L.; Roth, J.A.; Hofstetter, W.L.; Walsh, G.; Komaki, R.; Liao, Z.; Rice, D.C.; Vaporciyan, A.A.; Maru, D.M.; et al. A phase II randomized trial of induction chemotherapy versus no induction chemotherapy followed by preoperative chemoradiation in patients with esophageal cancer. Ann. Oncol. 2013, 24, 2844-2849. [CrossRef]

57. Semenkovich, T.R.; Samson, P.P.; Hudson, J.L.; Subramanian, M.; Meyers, B.F.; Kozower, B.D.; Kreisel, D.; Patterson, G.A.; Robinson, C.G.; Bradley, J.D.; et al. Induction Radiation Therapy for Esophageal Cancer: Does Dose Affect Outcomes? Ann. Thorac. Surg. 2019, 107, 903-911. [CrossRef]

58. Buckstein, M. Optimal radiation dose in the neoadjuvant management of esophageal cancer. J. Thorac. Dis. 2020, 12, 4568-4570. [CrossRef] [PubMed]

59. Buckstein, M.; Rhome, R.; Ru, M.; Moshier, E. Neoadjuvant chemoradiation radiation dose levels for surgically resectable esophageal cancer: Predictors of use and outcomes. Dis. Esophagus 2018, 31, dox148. [CrossRef]

60. Renehan, A.G.; Malcomson, L.; Emsley, R.; Gollins, S.; Maw, A.; Myint, A.S.; Rooney, P.S.; Susnerwala, S.; Blower, A.; Saunders, M.P.; et al. Watch-and-wait approach versus surgical resection after chemoradiotherapy for patients with rectal cancer (the OnCoRe project): A propensity-score matched cohort analysis. Lancet Oncol. 2016, 17, 174-183. [CrossRef]

61. Mehanna, H.; Wong, W.-L.; McConkey, C.C.; Rahman, J.K.; Robinson, M.; Hartley, A.G.J.; Nutting, C.; Powell, N.; Al-Booz, H.; Robinson, M.; et al. PET-CT surveillance versus neck dissection in advanced head and neck cancer. N. Engl. J. Med. 2016, 374, 1444-1454. [CrossRef]

62. Lou, D.Y.; Fong, L. Neoadjuvant therapy for localized prostate cancer: Examining mechanism of action and efficacy within the tumor. Urol. Oncol. Semin. Orig. Investig. 2016, 34, 182-192. [CrossRef] 
63. Stahl, M.; Stuschke, M.; Lehmann, N.; Meyer, H.-J.; Walz, M.K.; Seeber, S.; Klump, B.; Budach, W.; Teichmann, R.; Schmitt, M.; et al. Chemoradiation with and Without Surgery in Patients with Locally Advanced Squamous Cell Carcinoma of the Esophagus. J. Clin. Oncol. 2005, 23, 2310-2317. [CrossRef]

64. Bonnetain, F.; Bouché, O.; Michel, P.; Mariette, C.; Conroy, T.; Pezet, D.; Roullet, B.; Seitz, J.-F.; Paillot, B.; Arveux, P.; et al. A comparative longitudinal quality of life study using the Spitzer quality of life index in a randomized multicenter phase III trial (FFCD 9102): Chemoradiation followed by surgery compared with chemoradiation alone in locally advanced squamous resectable thoracic esophageal cancer. Ann. Oncol. 2006, 17, 827-834. [CrossRef] [PubMed]

65. Bedenne, L.; Michel, P.; Bouché, O.; Milan, C.; Mariette, C.; Conroy, T.; Pezet, D.; Roullet, B.; Seitz, J.-F.; Herr, J.-P.; et al. Chemoradiation Followed by Surgery Compared with Chemoradiation Alone in Squamous Cancer of the Esophagus: FFCD 9102. J. Clin. Oncol. 2007, 25, 1160-1168. [CrossRef]

66. Park, S.R.; Yoon, D.H.; Kim, J.H.; Kim, Y.-H.; Kim, H.R.; Lee, H.J.; Jung, H.-Y.; Lee, G.-H.; Song, H.J.; Kim, D.H.; et al. A Randomized Phase III Trial on the Role of Esophagectomy in Complete Responders to Preoperative Chemoradiotherapy for Esophageal Squamous Cell Carcinoma (ESOPRESSO). Anticancer Res. 2019, 39, 5123-5133. [CrossRef] [PubMed]

67. Fujita, H.; Sueyoshi, S.; Tanaka, T.; Tanaka, Y.; Matono, S.; Mori, N.; Mori, N.; Shirouzu, K.; Yamana, H.; Matsui, M.; et al. Esophagectomy: Is it necessary after chemoradiotherapy for a locally advanced T4 esophageal cancer? Prospective nonrandomized trial comparing chemoradiotherapy with surgery versus without surgery. World J. Surg. 2005, 29, 25-30. [CrossRef] [PubMed]

68. Noordman, B.J.; on behalf of the SANO-study group; Wijnhoven, B.P.L.; Lagarde, S.M.; Boonstra, J.J.; Coene, P.P.L.O.; Dekker, J.W.T.; Doukas, M.; van der Gaast, A.; Heisterkamp, J.; et al. Neoadjuvant chemoradiotherapy plus surgery versus active surveillance for oesophageal cancer: A stepped-wedge cluster randomised trial. BMC Cancer 2018, 18, 1-12. [CrossRef]

69. Jia, R.; Yin, W.; Li, S.; Li, R.; Yang, J.; Shan, T.; Zhou, D.; Wang, W.; Wan, L.; Zhou, F.; et al. Chemoradiation versus oesophagectomy for locally advanced oesophageal cancer in Chinese patients: Study protocol for a randomised controlled trial. Trials 2019, 20, 206. [CrossRef]

70. Noordman, B.J.; Spaander, M.C.W.; Valkema, R.; Wijnhoven, B.P.L.; Henegouwen, M.I.V.B.; Shapiro, J.; Biermann, K.; van der Gaast, A.; van Hillegersberg, R.; Hulshof, M.C.C.M.; et al. Detection of residual disease after neoadjuvant chemoradiotherapy for oesophageal cancer (preSANO): A prospective multicentre, diagnostic cohort study. Lancet Oncol. 2018, 19, 965-974. [CrossRef]

71. Castoro, C.; Scarpa, M.; Cagol, M.; Alfieri, R.; Ruol, A.; Cavallin, F.; Michieletto, S.; Zanchettin, G.; Sileni, V.C.; Corti, L.; et al. Complete Clinical Response After Neoadjuvant Chemoradiotherapy for Squamous Cell Cancer of the Thoracic Oesophagus: Is Surgery Always Necessary? J. Gastrointest. Surg. 2013, 17, 1375-1381. [CrossRef]

72. Taketa, T.; Xiao, L.; Sudo, K.; Suzuki, A.; Wadhwa, R.; Blum, M.A.; Lee, J.H.; Weston, B.; Bhutani, M.S.; Skinner, H.; et al. Propensity-Based Matching between Esophagogastric Cancer Patients Who Had Surgery and Who Declined Surgery after Preoperative Chemoradiation. Oncology 2013, 85, 95-99. [CrossRef] [PubMed]

73. Van der Wilk, B.J.; van Lanschot, J.J.B. Response to the Comment on "Active Surveillance Versus Immediate Surgery in Clinically Complete Responders After Neoadjuvant Chemoradiotherapy for Esophageal Cancer". Ann. Surg. 2020, 31. [CrossRef] [PubMed]

74. Furlong, H.; Bass, G.; Breathnach, O.; O'Neill, B.; Leen, E.; Walsh, T.N. Targeting therapy for esophageal cancer in patients aged 70 and over. J. Geriatr. Oncol. 2013, 4, 107-113. [CrossRef]

75. Stahl, M.; Walz, M.K.; Stuschke, M.; Lehmann, N.; Meyer, H.-J.; Riera-Knorrenschild, J.; Langer, P.; Engenhart-Cabillic, R.; Bitzer, M.; Königsrainer, A.; et al. Phase III Comparison of Preoperative Chemotherapy Compared with Chemoradiotherapy in Patients with Locally Advanced Adenocarcinoma of the Esophagogastric Junction. J. Clin. Oncol. 2009, 27, 851-856. [CrossRef] [PubMed]

76. Stahl, M.; Walz, M.K.; Riera-Knorrenschild, J.; Stuschke, M.; Sandermann, A.; Bitzer, M.; Wilke, H.; Budach, W. Preoperative chemotherapy versus chemoradiotherapy in locally advanced adenocarcinomas of the oesophagogastric junction (POET): Long-term results of a controlled randomised trial. Eur. J. Cancer 2017, 81, 183-190. [CrossRef]

77. Klevebro, F.; von Döbeln, G.A.; Wang, N.; Johnsen, G.; Jacobsen, A.B.; Friesland, S.; Lind, P.; Tsai, J.A.; Lundell, L.; Nilsson, M.; et al. A randomized clinical trial of neoadjuvant chemotherapy versus neoadjuvant chemoradiotherapy for cancer of the oesophagus or gastro-oesophageal junction. Ann. Oncol. 2016, 27, 660-667. [CrossRef] [PubMed]

78. Zhou, H.-Y.; Zheng, S.-P.; Li, A.-L.; Gao, Q.-L.; Ou, Q.-Y.; Chen, Y.-J.; Wu, S.-T.; Lin, D.-G.; Liu, S.; Huang, L.-Y.; et al. Clinical evidence for association of neoadjuvant chemotherapy or chemoradiotherapy with efficacy and safety in patients with resectable esophageal carcinoma (NewEC study). EClinicalMedicine 2020, 24, 100422. [CrossRef] [PubMed]

79. Nakamura, K.; Kato, K.; Igaki, H.; Ito, Y.; Mizusawa, J.; Ando, N.; Udagawa, H.; Tsubosa, Y.; Daiko, H.; Hironaka, S.; et al. Three-arm Phase III Trial Comparing Cisplatin Plus 5-FU (CF) Versus Docetaxel, Cisplatin Plus 5-FU (DCF) Versus Radiotherapy with CF (CF-RT) as Preoperative Therapy for Locally Advanced Esophageal Cancer (JCOG1109, NExT Study). Jpn. J. Clin. Oncol. 2013, 43, 752-755. [CrossRef] [PubMed]

80. Olayioye, M.A.; Neve, R.M.; Lane, H.A.; Hynes, N.E. NEW EMBO MEMBERS' REVIEW: The ErbB signaling network: Receptor heterodimerization in development and cancer. EMBO J. 2000, 19, 3159-3167. [CrossRef] 
81. Okawa, T.; Michaylira, C.Z.; Kalabis, J.; Stairs, D.B.; Nakagawa, H.; Andl, C.D.; Johnstone, C.N.; Klein-Szanto, A.J.; El-Deiry, W.; Cukierman, E.; et al. The functional interplay between EGFR overexpression, hTERT activation, and p53 mutation in esophageal epithelial cells with activation of stromal fibroblasts induces tumor development, invasion, and differentiation. Genes Dev. 2007, 21, 2788-2803. [CrossRef]

82. Song, J.; Shi, W.; Zhang, Y.; Sun, M.; Liang, X.; Zheng, S. Epidermal growth factor receptor and B7-H3 expression in esophageal squamous tissues correlate to patient prognosis. Oncotargets Ther. 2016, 9, 6257-6263. [CrossRef] [PubMed]

83. Yu, W.; Yang, X.; Chu, L.; Zhao, K.; Chen, H.; Xiang, J.; Zhang, Y.; Li, H.; Zhao, W.; Sun, M.; et al. Prognostic value of EGFR family expression in lymph node-negative esophageal squamous cell carcinoma patients. Pathol. Res. Pr. 2018, 214, 1017-1023. [CrossRef] [PubMed]

84. Ruhstaller, T.; Pless, M.; Dietrich, D.; Kranzbuehler, H.; Von Moos, R.; Moosmann, P.; Montemurro, M.; Schneider, P.M.; Rauch, D.; Gautschi, O.; et al. Cetuximab in Combination with Chemoradiotherapy Before Surgery in Patients with Resectable, Locally Advanced Esophageal Carcinoma: A Prospective, Multicenter Phase IB/II Trial (SAKK 75/06). J. Clin. Oncol. 2011, $29,626-631$. [CrossRef]

85. Lee, M.S.; Mamon, H.J.; Hong, T.S.; Choi, N.C.; Fidias, P.M.; Kwak, E.L.; Meyerhardt, J.A.; Ryan, D.P.; Bueno, R.; Donahue, D.M.; et al. Preoperative Cetuximab, Irinotecan, Cisplatin, and Radiation Therapy for Patients with Locally Advanced Esophageal Cancer. Oncologist 2013, 18, 281-287. [CrossRef] [PubMed]

86. Suntharalingam, M.; Winter, K.; Ilson, D.; Dicker, A.P.; Kachnic, L.; Konski, A.; Chakravarthy, A.B.; Anker, C.J.; Thakrar, H.; Horiba, N.; et al. Effect of the Addition of Cetuximab to Paclitaxel, Cisplatin, and Radiation Therapy for Patients with Esophageal Cancer. JAMA Oncol. 2017, 3, 1520-1528. [CrossRef] [PubMed]

87. Crosby, T.; Hurt, C.N.; Falk, S.; Gollins, S.; Staffurth, J.; Ray, R.; Bridgewater, J.A.; Geh, J.I.; Cunningham, D.; Blazeby, J.; et al. Long-term results and recurrence patterns from SCOPE-1: A phase II/III randomised trial of definitive chemoradiotherapy $+/-$ cetuximab in oesophageal cancer. Br. J. Cancer 2017, 116, 709-716. [CrossRef] [PubMed]

88. Mazorra, Z.; Chao, L.; Lavastida, A.; Sanchez, B.; Ramos, M.; Iznaga, N.; Crombet, T. Nimotuzumab: Beyond the EGFR signaling cascade inhibition. Semin. Oncol. 2018, 45, 18-26. [CrossRef]

89. Zhao, L.; He, L.-R.; Xi, M.; Cai, M.-Y.; Shen, J.-X.; Li, Q.-Q.; Liao, Y.-J.; Qian, D.; Feng, Z.-Z.; Zeng, Y.-X.; et al. Nimotuzumab promotes radiosensitivity of EGFR-overexpression esophageal squamous cell carcinoma cells by upregulating IGFBP-3. J. Transl. Med. 2012, 10, 249. [CrossRef]

90. Jing, W.; Yan, W.; Liu, Y.; Li, J.; Yu, J.; Zhu, H. Slight advantages of nimotuzumab versus cetuximab plus concurrent chemoradiotherapy in locally advanced esophageal squamous cell carcinoma. Cancer Biol. Ther. 2019, 20, 1121-1126. [CrossRef]

91. Chen, Y.; Wu, X.; Hao, D.; Cheng, X.; Zhang, L.; Zhang, Y.; Ke, S.; Shi, W.; He, C. Neoadjuvant nimotuzumab plus chemoradiotherapy compared to neoadjuvant chemoradiotherapy and neoadjuvant chemotherapy for locally advanced esophageal squamous cell carcinoma. Oncotarget 2018, 10, 4069-4078. [CrossRef] [PubMed]

92. Qi, S.; Mao, Y.; Jiang, M. A phase I study evaluating combined nimotuzumab and neoadjuvant chemoradiotherapy followed by surgery in locally advanced esophageal cancer. Cancer Chemother. Pharmacol. 2019, 84, 1115-1123. [CrossRef]

93. A Phase III Study of Nimotuzumab PlusConcurrent Chemoradiotherapy in Loco-regional EsophagealSquamous Cell Carcinoma. Available online: ClinicalTrials.gov (accessed on 12 June 2018).

94. Sun, D.; Yan, W.; Zhu, H.; Liu, Q.; Hou, H. Case Report: Primary and Acquired Resistance Mechanisms of Nimotuzumab in Advanced Esophageal Squamous Cell Carcinoma Revealed by Targeted Sequencing. Front. Oncol. 2020, 10, 574523. [CrossRef]

95. Moehler, M.; Maderer, A.; Thuss-Patience, P.; Brenner, B.; Meiler, J.; Ettrich, T.; Hofheinz, R.-D.; Al-Batran, S.; Vogel, A.; Mueller, L.; et al. Cisplatin and 5-fluorouracil with or without epidermal growth factor receptor inhibition panitumumab for patients with non-resectable, advanced or metastatic oesophageal squamous cell cancer: A prospective, open-label, randomised phase III AIO/EORTC trial (POWER). Ann. Oncol. 2020, 31, 228-235. [CrossRef]

96. Cunningham, D.; Stenning, S.P.; Smyth, E.C.; Okines, A.F.; Allum, W.H.; Rowley, S.; Stevenson, L.I.; Grabsch, H.; Alderson, D.; Crosby, T.; et al. Peri-operative chemotherapy with or without bevacizumab in operable oesophagogastric adenocarcinoma (UK Medical Research Council ST03): Primary analysis results of a multicentre, open-label, randomised phase 2-3 trial. Lancet Oncol. 2017, 18, 357-370. [CrossRef]

97. Rivera, F.; Jiménez, P.; Garcia Alfonso, P.; Lopez, C.; Gallego, J.; Limon, M.L.; Galan, M.; Falco, E.; Manzano, J.L.; Jorge, M.; et al. NEOHX study: Perioperative treatment with trastuzumab in combination with capecitabine and oxaliplatin (XELOX-T) in patients with HER-2 resectable stomach or esophagogastric junction (EGJ) adenocarcinoma-18 m DFS analysis. J. Clin. Oncol. 2015, 33, 107. [CrossRef]

98. Hofheinz, R.; Hegewisch-Becker, S.; Thuss-Patience, P.C.; Kunzmann, V.; Fuchs, M.; Graeven, U.; Homann, N.; Heinemann, V.; Pohl, M.; Al-Batran, S.E.; et al. HER-FLOT: Trastuzumab in combination with FLOT as peri-operative treatment for patients with HER2-positive locally advanced esophagogastric adenocarcinoma: A phase II trial of the AIO Gastric CancerStudy Group. J. Clin. Oncol. 2014, 32, 4073. [CrossRef]

99. Kato, K.; Cho, B.C.; Takahashi, M.; Okada, M.; Lin, C.-Y.; Chin, K.; Kadowaki, S.; Ahn, M.-J.; Hamamoto, Y.; Doki, Y.; et al. Nivolumab versus chemotherapy in patients with advanced oesophageal squamous cell carcinoma refractory or intolerant to previous chemotherapy (ATTRACTION-3): A multicentre, randomised, open-label, phase 3 trial. Lancet Oncol. 2019, 20, 1506-1517. [CrossRef] 
100. Noman, M.Z.; Desantis, G.; Janji, B.; Hasmim, M.; Karray, S.; Dessen, P.; Bronte, V.; Chouaib, S. PD-L1 is a novel direct target of HIF-1 $\alpha$, and its blockade under hypoxia enhanced MDSC-mediated T cell activation. J. Exp. Med. 2014, 211, 781-790. [CrossRef]

101. Yagi, T.; Baba, Y.; Ishimoto, T.; Iwatsuki, M.; Miyamoto, Y.; Yoshida, N.; Watanabe, M.; Baba, H. PD-L1 Expression, Tumorinfiltrating Lymphocytes, and Clinical Outcome in Patients with Surgically Resected Esophageal Cancer. Ann. Surg. 2019, 269, 471-478. [CrossRef] [PubMed]

102. Shah, M.A.; Kojima, T.; Hochhauser, D.; Enzinger, P.; Raimbourg, J.; Hollebecque, A.; Lordick, F.; Kim, S.-B.; Tajika, M.; Kim, H.T.; et al. Efficacy and Safety of Pembrolizumab for Heavily Pretreated Patients with Advanced, Metastatic Adenocarcinoma or Squamous Cell Carcinoma of the Esophagus. JAMA Oncol. 2019, 5, 546. [CrossRef]

103. Toshihiko Doi, T.; Piha-Paul, S.A.; Jalal, S.I.; Saraf, S.; Lunceford, J.; Koshiji, M.; Bennouna, J. Safety and Antitumor Activity of the Anti-Programmed Death-1 Antibody Pembrolizumab in PatientsWith Advanced Esophageal Carcinoma. J. Clin. Oncol. 2018, 36, 61-67. [CrossRef]

104. Kojima, T.; Shah, M.A.; Muro, K.; Francois, E.; Adenis, A.; Hsu, C.-H.; Doi, T.; Moriwaki, T.; Kim, S.-B.; Lee, S.-H.; et al. Randomized Phase III KEYNOTE-181 Study of Pembrolizumab Versus Chemotherapy in Advanced Esophageal Cancer. J. Clin. Oncol. 2020, 38, 4138-4148. [CrossRef] [PubMed]

105. Koyanagi, K.; Kanamori, K.; Ninomiya, Y.; Yatabe, K.; Higuchi, T.; Yamamoto, M.; Tajima, K.; Ozawa, S. Progress in Multimodal Treatment for Advanced Esophageal Squamous Cell Carcinoma: Results of Multi-Institutional Trials Conducted in Japan. Cancers 2020, 13, 51. [CrossRef]

106. Shen, D.; Chen, Q.; Wu, J.; Li, J.; Tao, K.; Jiang, Y. The safety and efficacy of neoadjuvant PD-1 inhibitor with chemotherapy for locally advanced esophageal squamous cell carcinoma. J. Gastrointest. Oncol. 2021, 12, 1-10. [CrossRef] [PubMed]

107. Wu, Z.; Zheng, Q.; Chen, H.; Xiang, J.; Hu, H.; Li, H.; Pan, Y.; Peng, Y.; Yao, X.; Liu, P.; et al. Efficacy and safety of neoadjuvant chemotherapy and immunotherapy in locally resectable advanced esophageal squamous cell carcinoma. J. Thorac. Dis. 2021, 13, 3518-3528. [CrossRef]

108. Zhang, L. PERFECT trial results: Combining neoadjuvant chemoradiotherapy with atezolizumab is feasible in resectable esophageal adenocarcinoma. Thorac. Cancer 2021, 12, 1797-1799. [CrossRef]

109. Deng, L.; Liang, H.; Burnette, B.; Beckett, M.; Darga, T.; Weichselbaum, R.R.; Fu, Y.-X. Irradiation and anti-PD-L1 treatment synergistically promote antitumor immunity in mice. J. Clin. Investig. 2014, 124, 687-695. [CrossRef]

110. Dovedi, S.J.; Adlard, A.; Lipowska-Bhalla, G.; McKenna, C.; Jones, S.; Cheadle, E.J.; Stratford, I.J.; Poon, E.; Morrow, M.; Stewart, R.; et al. Acquired Resistance to Fractionated Radiotherapy Can Be Overcome by Concurrent PD-L1 Blockade. Cancer Res. 2014, 74, 5458-5468. [CrossRef]

111. Park, S.; Dong, H.; Liu, X.; Harrington, S.M.; Krco, C.J.; Grams, M.P.; Mansfield, A.; Furutani, K.M.; Olivier, K.R.; Kwon, E.D. PD-1 Restrains Radiotherapy-Induced Abscopal Effect. Cancer Immunol. Res. 2015, 3, 610-619. [CrossRef] [PubMed]

112. Kelly, R.J.; Ajani, J.A.; Kuzdzal, J.; Zander, T.; Van Cutsem, E.; Piessen, G.; Mendez, G.; Feliciano, J.; Motoyama, S.; Moehler, M.; et al. Adjuvant Nivolumab in Resected Esophageal or Gastroesophageal Junction Cancer. N. Engl. J. Med. 2021, 384, 1191-1203. [CrossRef] 